\title{
İNŞAAT SÖZLEŞMELERİNDE TARAFLARIN İŞ BİRLİĞİ EYLEMLERİ
}

\author{
Arş. Gör. Dr. İpek Betül ALDEMİR TOPRAK*
}

\section{ÖZET}

İnşaat sözleşmesi, uygulamada birden fazla türe sahiptir. Bunlar basit bir eserin imalinden, karmaşık bir tesisin inşasına kadar uzanır. İşs sahibi, bu sözleşmelerde ücret ödeyebilir, mülkiyet hakkını devredebilir veya gelir paylaşabilir. Ancak bütün bu inşaat sözleşmesi türleri için ortak olan özellik, iş sahibinin edimi karşllı̆̆ında yüklenicinin, bir eser inşa etmesidir. Aynı zamanda bir eserin sözleşmede kararlaştıııldığı şekilde inşası için tarafların ifa süresince birlikte çalışması gerekir. İş birliği yapmaktan kaçınma, diğer tarafın edimini zamanında yerine getirmesine engel olabilir. Eserin ayıplı veya inşasının imkânsız olması mümkündür.

İnşaat sözleşmesinde tarafların yerine getirecekleri iş birliği eylemleri, hukukumuzda yasal bir düzenlemeye sahip değildir. Bu sebeple, iş birliği eylemlerinin hukukî niteliği hakkında özel bir hüküm bulunmamaktadır. Dolayısıyla, iş birliği eylemlerine aykırılık halinde uygulanacak kurallar belirlenmelidir. Çalışmada, iş birliği eylemlerinin hukukî niteliği ve bu eylemlere uygulanacak hükümler belirlenmiştir. Bu belirlemede, yer yer Alman ve İsviçre Hukukunda yer alan görüşlere ve yasal düzenlemelere yer verilmiştir. İş birliği eylemleri, tüm inşaat sözleşmelerinde bulunmaktadır. Ancak tarafların, hangi iş birliği eylemlerini yerine getirmek zorunda oldukları, her bir sözleşmenin özelliklerine göre farklılık arz eder. Buna rağmen, tarafların sahip oldukları iş birliği eylemlerinin başlıcaları, çalışmamızda yer almaktadır. Bu iş birliği eylemleri, sözleşme, doktrin, mahkeme kararları veya çeşitli yasal düzenlemeler aracılığıyla belirlenmeye çalışlmıştır.

Anahtar Kelimeler: İş Birliği Eylemi, İnşaat Sözleşmesi, Eser Sözleşmesi, Külfet, Yükümlülük.

Ankara Yıldırım Beyazıt Üniversitesi Hukuk Fakültesi, Medenî Hukuk Anabilim Dalı, ibaldemir@ybu.edu.tr, ORCID ID: 0000-0003-0721-3044, (Geliş Tarihi: 17.03.2020 - Kabul Tarihi: 27.06.2020). 


\section{MITWIRKUNGSHANDLUNG DER PARTEIEN BEI BAUVERTRÄGEN}

\section{ZUSAMMENFASSUNG}

Der Bauvertrag hat mehrere Arten in der Praxis. Diese reichen von der Installation eines einfachen Bauwerkes bis zum Bau einer komplexen Anlage. Der Auftraggeber kann in diesen Verträgen Vergütung zahlen, Eigentumsrechte übertragen oder Erträge teilen. Das gemeinsame Merkmal für alle diese Arten von Bauverträgen ist jedoch, dass der Auftragnehmer ein Werk im Austausch für die Leistung des Auftraggebers baut. Gleichzeitig müssen die Parteien während der Ausführung zusammenarbeiten, um ein im Vertrag vereinbartes Werk einzurichten. Die Vermeidung einer Zusammenarbeit kann die andere Partei daran hindern, rechtzeitig zu ausführen. Es ist möglich, dass das Werk Mangel hat oder unmöglich zu bauen ist.

Die Mitwirkungshandlung, die die Parteien im Bauvertrag durchführen werden, haben keine rechtliche Regelung in unserem Recht. Aus diesem Grund gibt es keine spezifische Bestimmung über den rechtlichen Charakter von Mitwirkungshandlungen. Die Regeln sind auch zu festlegen, die bei Verstößen gegen Mitwirkungshandlung anzuwenden sind. In der Studie wurden Rechtsnatur der Mitwirkungshandlungen und die anzuwendenden Regeln festgelegt. Diese Bezeichnung umfasst Meinungen und rechtliche Regelungen im deutschen und schweizerischen Recht. Die Mitwirkungshandlung findet sich in allen Bauverträgen. Welche Mitwirkungshandlung die Parteien durchführen müssen, wird sich jedoch je nach den Merkmalen jedes Vertrags unterscheiden. Trotzdem sind die hauptsächlichen der Mitwirkungshandlungen, die die Parteien haben, in unserer Studie enthalten.

Schlüsselwörter: die Mitwirkungshandlung, der Bauvertrag, der Werkvertrag, die Obliegenheit, die Verpflichtung. 


\section{GİRIŞ}

"İnşa" kelimesi, Arapça kökenlidir. Bir yapıyı meydana getirme ve oluşturma anlamlarına gelmektedir. "İş̧aat" ise yapma işi, yapım anlamlarında kullanılır ${ }^{1}$ ve inşa kelimesinin çoğuludur. Barınma ve işyeri gibi ihtiyaçları karşılamak amacıyla bir şeyler inşa etme, insanoğlunun varoluşundan beri temel uğraşlarından biridir. Zira sürekli artan nüfus, bunlara olan ihtiyacı da artırmaktadır. Bir inşa eserinin yapımını konu alan inşaat sektöründe, kişiler arasındaki hukukî ilişkiler, “inşaat sözleşmeleri” ile düzenlenir. İnşaat sözleşmeleri, uygulamada farklı görünüm türlerine sahiptir. $\mathrm{Bu}$ türler, tarafların eser inşa etmekle amaçladıkları sonuçlara göre şekillenmektedir. Bunlardan ilki, Türk Borçlar Kanunu'nda düzenlenmiş eser sözleşmesi kapsamında yapılan genel nitelikteki inşaat sözleşmesidir. Burada yüklenici, iş sahibinden alacağı ücret karşılığında, bir yapıyı meydana getirmeyi üstlenir (TBK m. 470). Ancak bazı durumlarda iş sahibi, inşa eserinin meydana getirilmesi karşıllğında ücret ödemek istemez. Bu halde, iş sahibinin edimine göre arsa payı karşılığı, gelir paylaşımlı veya işletme hakkı karşılığı inşaat sözleşmesi söz konusu olabilir. Bunun dışında iş sahibi ücret ödeyecek olmasına rağmen, karmaşık bir tesisin sorunsuz çalışır şekilde teslimini isteyebilir. Bu halde de anahtar teslim inşaat sözleşmesi söz konusu olur $^{2}$. Kanaatimizce tüm bu inşaat sözleşmelerinde, iş sahibinin yükleniciye eserin meydana getirilmesi için vereceği karşılık farklılık arz etse de ortak olan özellik, iş birliği eyleminde bulunmasıdır. Aynı şekilde, yüklenicinin de sözleşmede kararlaştırıldığ1 şekilde bir eseri meydana getirebilmesi için iş sahibi ile iş birliği yapması gerekmektedir.

İnşaat sözleşmeleri, Alman Medenî Kanunu’nun (BGB $\$$ 650a f.) aksine Türk Borçlar Kanunu'nda düzenlenmemektedir. Dolayısıyla, inşaat

Bilgi için bkz.

$<$ http://www.tdk.gov.tr/index.php?option=com_gts\&kelime=\%C4\%B0N\%C5\%9EAAT $>$ s.e.t. 16.03 .2020 .

2 İnşaat sözleşmesinin türleri, aralarındaki benzerlik ve farklılıklar için bkz. Kurşat, Zekeriya (2017) İnşaat Sözleşmesi, Filiz Kitabevi, s. 4 vd.; Aldemir Toprak, İpek Betül (2020) Anahtar Teslim İnşaat Sözleşmesi, Seçkin Yayıncılık, s. 107-115. İnşaat sözleşmelerinin türlerine ilişkin farklı bir ayrım için bkz. Bauer, Hermann (2007) Baubetrieb, 3. Aufl., Berlin Heidelberg, Springer Verlag, s. 41. 
sözleşmelerinde tarafların yapmaları gereken iş birliği eylemlerine de kanunda yer verildiği söylenemez. Öte yandan, kanunumuzun eser sözleşmesi bahsinde de iş birliği eylemlerine yer verilmediği görülmektedir. Yalnız kamu tüzel kişilerinin taraf olduğu inşaat sözleşmelerine uygulanacak olan düzenlemelerde, birkaç hüküm ile iş birliği eyleminden bahsedildiği söylenebilir. Ancak uzun bir ifa sürecini kapsayan ve süre veya maliyet bakımından birçok riski taşıyan inşaat sözleşmeleri için bu düzenlemeler, gerek hukukî niteliğin ve türlerin belirlenmesinde gerekse de ihlâl halinde hangi yaptırımların uygulanacağını tespitte yeterli değildir. $\mathrm{Bu}$ sebeple, çalışmamızda inşaat sözleşmesi uygulamaları, doktrin, mahkeme kararları ile yer yer İsviçre SIA-Norm 118 ve Alman BGB ile VOB/B düzenlemelerine karşılaştırmalı olarak yer verilmektedir.

\section{I. İŞ BİRLİĞİ TERİMI}

İnşaat sözleşmelerinin konusunu, geniş anlamda inşa eseri (yapı) ${ }^{3}$ oluşturur. İnşaat sözleşmesi ile taraflar, bir inşa eserinin meydana getirilmesini amaçlarlar. Ancak bu edim sonucunun gerçekleştirilmesi, sadece yüklenicinin veya iş sahibinin bireysel olarak gerçekleştirecekleri faaliyetlere bağlı değildir. İnşaat sözleşmelerinin gerçekleştirilmesinde, iş sahibi ve yüklenicinin birlikte hareket etmesi, iş birliği yapması gereken durumlar söz konusudur.

İş birliği terimi, Latince "cooperatio" kelimesinden türemiştir ve etkileşim (Zusammenwirken) veya birlikte çalışma (Zusammenarbeit)

3 Yapı, barınmak veya başka amaçlarla kullanılmak için yapılmış her türlü mimarlık eseri ya da binayı ifade etmektedir. Bkz. <https://sozluk.gov.tr/> s.e.t. 16.06.2020. İnşa eseri ve yapı, eş anlamlı olup eser kavramından daha dardır. Bkz. Eren, Fikret (1996) I. Borçlar Kanunu Açısından İnşaat Sözleşmeleri; II İnşaat Sözleşmelerinde Müteahhidin Borçları ve Bu Borçların Yerine Getirilmemesinin Sonuçları; III. İnşaat Sözleşmesinin Sona Ermesi, Yönetici-İşletmeci-Mühendis ve Hukukçular İçin Ortak Seminer, Banka ve Ticaret Hukuku Araştırma Enstitüsü Yayınları, 3. Tıpkı Basım, s. 47-103, Ankara, s. 53; Aydemir, Efrail (2016) Eser Sözleşmesi ve İnşaat Hukuku, Güncellenmiş 3. Baskı, Seçkin Yayıncılık, Ankara, Haziran, s. 37; Aldemir Toprak, s. 46-47. Ancak çalışma kapsamında, söz konusu tüm kavramlar kullanılmış olup anlatılmak istenen, yüklenicinin imal etmekle yükümlü olduğu inşa eseridir. 
anlamlarına gelmektedir ${ }^{4}$. İş birliği teriminden, eserin türüne, özelliğine ve sözleşmenin içeriğine göre kararlaştırıldığı şekilde meydana getirilmesi için gerekli olan eylemler anlaşılır ${ }^{5}$. Diğer bir ifadeyle, iş birliği, sözleşme amacına ulaşılması için tarafların birlikte çalışmasını ifade eder. İş birliğinin ön koşulu, bu ilişkideki kişilerin farklılıklarının tanınmasıdır. Ayrıca bu kişilerin farklı çıkar durumlarının, iş birliği ilişkisiyle, organize edilmesi ve yapılandırılması gerekir. Böylelikle, görevi birlikte yerine getirme anlayışı oluşur ${ }^{6}$.

Doktrinde ve mahkeme kararlarında, taraflar arasındaki birlikte çalışmayı ifade eder şekilde farklı terimler kullanılmaktadır. Söz konusu bu kullanımlar, iş birliğinin gerçekleştirilmesine ilişkin eylemin nasıl nitelendirildiğinden etkilenmektedir. Örneğin, Alman Hukukunda ${ }^{7}$ iş birliği eylemini ifade eder şekilde yer yer "iş birliği yükümlülüğ̈̈" (Mitwirkungspflicht ${ }^{8}$, Kooperationspflicht ${ }^{9}$ ), “iş birliği eylemi"

4 Schwarze, Torsten (2003) Das Kooperationsprinzip des Bauvertragsrecht, Berlin, TENEA Verlag Für Medien, s. 7. Almanca iş birliği terimi "kooperation", genel konuşma dilinde Almanca "mitwirkung" ve "zusammenarbeit" kavramlarıla da ifade edilmektedir. Bkz. Fuchs, Heiko (2003) Kooperationspflichten der Bauvertragspartein, Baurechtliche Schriften Band 58, (Hrsg. Koorbion, H./ Locher, H.), München, Werner Verlag, s. 66.

5 Palandt, Otto (2018) Bürgerliches Gesetzbuch mit Nebengesetzen, (bearbeitet von Brudermüller, Ellenberger, Götz, Grüneberg, Herrler, Sprau, Thorn, Weidenkaff, Weidlich, Wicke), 77. neubearbeitete Aufl., München, Verlag C.H. Beck, $₫ 642$ Rn. 2. İş birliği teriminin diğer tanımları için bkz. Schwarze, s. 7-9; Fuchs, s. 45 vd; Ünal, Akın (2019) “Eser Sözleşmesinde İş Sahibinin İşbirliği Yapma Ödevi”, ERÜHFD, C: XIV, S: 2, s. 441456, s. 444.

6 Schwarze, s. 8.

7 Doktrinde ve mahkeme kararlarında “iş birliği (Kooperationsverpflichtung), "iş birliği karakteri” (Kooperationscharakter), "iş birliği ilişkisi” (Kooperationsverhältnis) ve “iş birliği gerekliliği” (Kooperationserfordernis) ifadelerinin kullanıldığı yönündeki görüş için bkz. Fuchs, s. 65.

8 Nicklisch, Fritz (1979) "Mitwirkungspflichten des Bestellers beim Werkvertrag, insbesondere beim Bau- und Industrieanlagenvertrag", BB 1979, Heft 11, s. 533-544, s. 533; Schwarze, s. 55; Peters, Frank (2011) "Die Mitwirkung des Bestellers bei der Durchführung eines Bauvertrags” NZBau 2011, Heft 11, s. 641-645, s. 643; Esser, Josef/ Weyers, Hans-Leo (1991) Schuldrecht: Ein Lehrbuch: Band II: Besonderer Teil, 7., völlig neuebearbeitete Auflage, Heidelberg, C. F. Müller Juristischer Verlag, s. 285. 
(Mitwirkungshandlung) ${ }^{10}$, “iş birliği külfeti” (Mitwirkungsobliegenheit) ${ }^{11}$ terimlerini kullanmaktadır. Türk Hukukunda ise "iş birliği ödevi”"12 " "iş birliği yapma borcu"13 veya "edimin ifasına katılma"14 terimleri, birlikte çalışmayı ifade etmektedir. Ancak bu çalışmada, hukukî nitelik, külfet veya yükümlülük olarak baştan kesin bir şekilde belirlenmediği için ${ }^{15}$ "iş birliği eylemleri" ifadesinin kullanımı tercih edilmektedir.

9 Fuchs, s. 3; Stassen, Dieter/ Grams, Hartmut (2003) “Zur Kooperationspflicht des Auftragnehmers gemäß $\$ 2$ Nr. 5 VOB/B 2002 bei Mehrkosten”, baurecht 2003, Heft 7, s. 943-952, s. 943.

Nicklisch, s. 533; Schwarze, s. 18; Erman, Walter Alexander (2011) Bürgerliches Gesetzbuch, (Hrsg. Harm Peter Westermann/ Barbara Grunewald/ Georg Maier-Reimer), 13., neu bearbeitete Aufl., Köln, Verlag Dr. Otto Schmidt, BGB $\$ 643$ Rn. 1; Larenz, Karl (1986) Lehrbuch des Schuldrechts Band II: Besonderer Teil, 1. Halbband, 13. Aufl., München, C.H. Beck'sche Verlagsbuchhandlung, s. 370; Gauch, Peter (1995) "Fristen und Termine - Die Bauzeit im Werkvertrag", Semınar für Schweızerisches Baurecht, Baurechtstagung 1995 / Tagungsunterlage 1, Freibrug, s. 23; Kapellmann, Klaus Dieter (2011) "Die erforderliche Mitwirkung nach $\$ 642$ BGB, $\$ 6$ VI VOB/B - Vertragspflichten und keine Obliegenheiten”, NZBau 2011, Heft 4, s. 193-197, s. 193; Locher, Horst/ Locher, Ulrich (2005) Das private Baurecht, Lehrbuch für Studium und Praxis, 7. Neubearbeitete Aufl., München, Verlag C.H. Beck, s. 60 Rn. 133. Aynı kullanım için bkz. BGH, Urteil vom 21.10.1999- VII ZR 185/98 (München), NJW 2000, 1336; BGH, Urteil vom 20.04.2017 - VII ZR 194/13, NJW 2017, 2025.

11 Peters, s. 644. Sadece "mitwirkung" kullanımı için bkz. Larenz, Karl (1987) Lehrbuch des Schuldrechts Band I: Allgemeiner Teil, 14. Aufl., München, C.H. Beck'sche Verlagsbuchhandlung, s. 389-390; Fikentscher, Wolfgang/ Heinemann, Andreas (2017) Schuldrecht Allgemeiner und Besonderer Teil, 11., völlig neu bearbeitete Aufl., Berlin/ Boston, Walter de Gruyter GmbH, $\$ 45$ Rn. 489; Staudinger, Julius (2008) Kommentar zum Bürgerlichen Gesetzbuch: Staudinger BGB - Buch 2: Recht der Schuldverhältnisse: $\$ \$$ 631-651 (Werkvertragsrecht), Neubearbeitung, Berlin, Sellier- de Gruyter, s. 115 Rn. 62.

12 Ünal, s. $441 \mathrm{vd}$.

13 Seçer, Öz (2017) "İş Sahibinin Teslim Borcundaki Gecikmeden Dolayı Sorumluluğu”: Baysal, Başak/ İnal, Emrehan, İnşaat Hukuku ve Uygulaması, 1. Baskı, İstanbul, On İki Levha Yayıncilik, s. 485.

14 Arpacı, Özge (2019) Eser Sözleşmesinde İş Sahibinin Edimin İfasına Katılımı, Ankara, Yetkin Yayınları, s. 55.

15 Kapsamlı bilgi için bkz. aşa. III, D. 


\section{II. İNŞAAT SÖZLEŞMELERİNDE GENEL OLARAK İ̧ BİRLİĞİ EYLEMLERI}

İnşaat sözleşmesinde esas itibariyle, yüklenici, bir inşa eseri imal etmeyi; iş sahibi ise ücret ödemeyi borçlanmış olsa da diğer tarafın meydana getirilmesine hizmet eden bazı eylemleri bulunur. $\mathrm{Bu}$ eylemler, eserin kararlaştırıldığ 1 şekilde meydana getirilmesi için büyük önem arz eder. Ayrıca bu eylemler, inşa eserinin meydana getirilmesinden önce, teslime kadar uzanan tüm süreci kapsar.

Sözleşme hukukunda, borçlunun bazı edimlerinde borcun yerine getirilebilmesi için, alacaklının iş birliğinin gerekli olduğu düşüncesi vardır ${ }^{16}$. Eser sözleşmesinin ifasında, kural olarak iş sahibi ve yüklenicinin, iş birliğinde bulunması gerektiği ifade edilmektedirr ${ }^{17}$. Öyle ki, bir görüş ${ }^{18}$ de iş sahibi ve yüklenicinin iş birliği olmaksızın eserin meydana getirilmesinin mümkün olmadığını ifade etmektedir. Nitekim inşaat sözleşmelerinde, karşılıklı ilişkiyi zorlaştıran iş birliği engellerinin var olduğu düşüncesi, iş birliği eylemlerinin incelenmesinin hareket noktasını oluşturur ${ }^{19}$. Bu sebeple, inşaat sözleşmesinin taraflarının, iş birliğinde bulunmak zorunda olduğu ifade edilmektedir ${ }^{20}$. Zira inşaat projelerinin giderek daha karmaşık bir hal alması ve proje başarısının her zaman risk altında olması, iş birliği eylemlerine verilen önem ile duyulan gereksinimi de arttırmaktadır. Öyle ki, söz konusu iş birliği eylemlerinin yerine getirilmemesi halinde, yapının inşası zaman, süre ve maliyet bakımından riske girebilmekte, olumsuz sonuçlar ortaya çıkabilmektedir.

İş birliği eylemleri, sözleşme başarısı için gerekli olmasına rağmen, kanun koyucu tarafından düzenlenen genel bir hüküm bulunmamaktadır. Nitekim, İsviçre Hukukunda da böyle bir hüküm yoktur. Bunun aksine, iş birliği eylemleri, her iki hukuk sisteminde doktrin ve yargı kararları ile

Fikentscher/ Heinemann, $₫ 45$ Rn. 489.

17 Nicklisch, s. 533. Eser sözleşmesinde iş sahibi ve yüklenicinin neredeyse her zaman iş birliği yapmaları gerektiği yönünde bkz. Esser/ Weyers, s. 285.

18 Kapellmann, s. 198; Nicklisch, s. 533; Larenz, 1986, s. 370. İnşaat sözleşmelerinde iş birliği eylemlerine duyulan ihtiyaç hakkında kapsamlı bilgi için bkz. Fuchs, s. 93 vd.

19 Fuchs, s. 169.

20 Bu konudaki açıklama için bkz. Stassen/ Grams, s. 947. 
şekillenmektedir. Yine bu noktada, sözleşme içeriği ve uygulamalar ile iş birliği eylemi oluşabilmektedir. Ancak İmar Kanunu (İK), Bayındırlık İşleri Genel Şartnamesi (BİGŞ) ve Yapım İşleri Genel Şartnamesi (YİGŞ) gibi düzenlemelerde de çeşitli iş birliği eylemelerine yer verildiği görülmektedir. İsviçre Hukukunda ise SIA-Norm $118^{21}$ düzenlemesi içerisinde iş birliği eylemlerine yer verildiği görülmektedir.

İsviçre ve Türk Hukukunun aksine Alman Medenî Kanunu, 01.01.2018 tarihinde inşaat sözleşmesi reformları ile modernize edilerek, iş birliği eylemleri birkaç hükümle düzenlenmiştir. Ancak bu düzenlemelere, inşaat sözleşmesi alanında değil, eser sözleşmesi bahsinde yer verilmektedir. Söz konusu düzenlemelerde, iş sahibinin iş birliği eylemlerinin türleri düzenlenmemektedir. Bunun yerine iş sahibinin iş birliği eylemlerini yerine getirmemesinin sonuçları ele alınmaktadır (BGB $\$ 642 \mathrm{f}$.). $\mathrm{VOB} / \mathrm{B}^{22}$ de ise iş sahibinin çok sayıda iş birliği eylemi, ayrıca düzenlenmektedir. Doktrin ve mahkeme kararları ise $\mathrm{VOB} / \mathrm{B}$ 'de yer alan iş birliği eylemlerinin, genellikle Alman Medenî Kanunu kapsamındaki eser sözleşmelerine de uygulanacağını ileri sürmektedir ${ }^{23}$.

21 SIA-Norm 118 ise İsviçre'de Mühendis ve Mimarlar Derneği tarafından oluşturulan bir düzenlemedir. SIA-Norm 118, inşaat sözleşmesinin yapılmasına ve uygulanmasına ilişkin eser sözleşmesinden ayrı ve özel hükümler içermektedir. Bkz. Gauch, Peter (2011) Der Werkvertrag, 5. überarbeitete und erweiterte Aufl., Zürich, Schulthess Juristische Medien AG, Rn. 261-262, Rn. 265.

22 Alman VOB kuralları, inşaat işlerine ilişkin ihale ve sözleşme koşullarını düzenlemektedir. VOB, A, B ve C olarak adlandırılan üç kısımdan oluşur. Bunlardan VOB/B, Alman Medenî Kanunu'nun eser sözleşmesine ilişkin hükümlerini, inşaat işlerinin özel durumları için tamamlar ve uyarlar. $\mathrm{VOB} / \mathrm{B}$, yalnız kamu tüzel kişilerinin taraf olduğu inşaat işlerinde uygulanmaz. Aksine VOB/B özel sektörde de yaygın şekilde kullanılır. Bkz. Locher/ Locher, s. 65 Rn. 140; Vygen, Klaus/ Joussen, Edgar (2008) Bauvertragsrecht nach VOB und BGB, Handbuch des privaten Baurechts, 4. neu bearbeitete und erweiterte Aufl., Köln, Werner Verlag, s. 163 Rn. 426. VOB/B düzenlemeleri, kanun veya yönetmelik niteliğine sahip değildir. Niteliği itibariyle, genel işlem kuralı olduğu için taraflar arasındaki hukukî ilişkiye, VOB/B kurallarının uygulanacağı açıkça kararlaştırılmalıdır. Bkz. Vygen/ Joussen, s. 13 Rn. 26, s. 163 Rn. 426; Kleine-Möller, Nils/ Merl, Heinrich/ Glöckner, Jochen (2014) Handbuch des privaten Baurechts, 5., neu bearbeitete und erweiterte Aufl., München, C.H. Beck Verlag, § 2 Rn. 39; Staudinger, s. 54 Rn. 94.

Schwarze, s. 18-19. 
Tarafların yerine getirecekleri iş birliği eylemleri, tüm inşaat sözleşmelerinde aynı değildir. Öyle ki, inşaat sözleşmelerinde ihtiyaç duyulan iş birliği eylemlerinin türleri, projenin büyüklüğüne ve karmaşıklığına göre değişiklik arz etmektedir ${ }^{24}$. Söz konusu inşa eserinin niteliği, yapının özelliği ve diğer katılımcıların varlığı, iş birliğini, kapsam, sayı, süre veya tür olarak farklılaştırmaktadır. Bu bakımdan, bir evin inşasını konu alan inşaat sözleşmesi ile katı atık yakma tesisinin meydana getirilmesini amaçlayan anahtar teslim inşaat sözleşmelerinde, tarafların aynı kapsam ve sayıda iş birliği eylemi gerçekleştirmekle yükümlü oldukları söylenemez. Ancak bir inşa eserinin meydana getirilmesini konu alan tüm inşaat sözleşmeleri için ortak olan nokta, iş birliği eylemlerinin varlığıdır. Bu bakımdan, iş birliği eylemleri her $\mathrm{r}$ sözleşmede farklı olsa da bu eylemlerin tipik örneklerini sıralamak mümkündür. Bunları inşaat plânların hazırlanması ${ }^{25}$, izin veya onayların alınmass $^{26}$, şantiyedeki düzenin sürdürülmesi ${ }^{27}$ oluşturur. Yine inşaat arsasının

24 Kapellmann, s. 198; Nicklisch, s. 533; Aldemir Toprak, s. 235.

Schwarze, s. 20; Säcker, Franz Jürgen/ Rixecker, Roland/ Oetker, Hartmut/ Limperg, Bettina (Hrsg.) (2018) Münchener Kommentar zum Bürgerlichen Gesetzbuch, Band 5/1, Schuldrecht-Besonderer Teil III/1, 7. Aufl., München, C.H. Beck. (Kisaca: MüKoBGB/ Bölüm Yazarının Adı), BGB $\$ 642$ Rn. 11, BGB $₫ 631$ Rn. 108; Gauch, 2011, Rn. 1332-1333; Nicklisch, s. 534, 538; Eren, 2019, s. 1135; Kleine-Möller/ Merl/ Glöckner, \$ 2 Rn. 24; Esser/ Weyers, s. 285; Ünal, s. 445; Spiess, Hans Rudolf (2012) "Bauablaufstörungen im schweizerischen Werkvertragsrecht”, recht 2012, Heft 4, s. 116-123, s. 120; Peters, s. 645; Staudinger, s. 115 Rn. 62. Kapsamlı bilgi için bkz. aşa. IV, A, 4.

Gauch, 2011, Rn. 1331; Schwarze, s. 20; Vasconcellos, Harald Michaelis (1988) Garantieklauseln und Risikoverteilung im internationalen Anlagenvertrag, Heidelberg, Verlag Recht und Wirtschaft GmbH, s. 94; MüKoBGB/Busche, BGB $\$ 642$ Rn. 11; Nicklisch, s. 534, 538; Vygen/ Joussen, s. 417 Rn. 1062; Kleine-Möller/ Merl/ Glöckner, $\$ 2$ Rn. 24; Müller-Foell, Christoph (1982) Die Mitwirkung des Bestellers beim Werkvertrag, Schriften zum Bürgerlichen Recht, Band 69, Berlin, Duncker \& Humblot, s. 88; Eren, 2019, s. 1135; Staudinger, s. 263-264 Rn. 34; Ünal, s. 445; Öz, M. Turgut (2016) İnşaat Sözleşmesi ve İlgili Mevzuat, İstanbul, Vedat Kitapçılık, s. 114; Peters, s. 645; Palandt, $\$ 642$ Rn. 2; Kapellmann, s. 193; Aldemir Toprak, s. 239. Ayrıca bkz. VOB/B $₫ 4$, BİGŞ m. 6 ve YİGŞ m. 8. Kapsamlı bilgi için bkz. aşa. IV, A, 3.

Bkz. VOB/B $₫ 4$. 
ölçümlenmesi ${ }^{28}$, hazırlanması ve teslimi ${ }^{29}$, tedarik hatlarının inşası ${ }^{30}$, yüklenicinin ifaya çağrılması ${ }^{31}$ bu kapsamdadır. İnşaat işlerinin gerçekleştirilmesi genel veya tam yükleniciye verilmemişse, yüklenicilerin iş sahibi tarafından zaman ve fonksiyonel olarak koordine edilmesi de iş birliği eylemidir $^{32}$. Endüstriyel tesislerin inşasını konu alan sözleşmelerde, iş birliği eylemleri bunlarla sınırlı değildir ${ }^{33}$. İşlevsellik testlerine katılma, ham madde veya personel temin etme, iş sahibinin iş birliği eylemi olarak görülmektedir ${ }^{34}$. Eserin zaman zaman yüklenicinin ülkesi dışında ve iş sahibinin ülkesinde imal edilmesi halinde, söz konusu iş birliği eylemlerine yenileri eklenir. Bunlar, yüklenicinin personeli için geçici kalacak yer hazırlanmasıdır ${ }^{35}$. Yine kanaatimizce çalışma izinlerinin ve gerekli ise ikamet izinlerinin alınması bu kapsamda değerlendirilebilir. Bahsi geçen iş birliği eylemlerinin doktrin ${ }^{36}$ ve

28 Bkz. VOB/B § 3. Ayrıca bkz. Schwarze, s. 21; Arpacı, s. 139; Fuchs, s. 1045; Locher/ Locher, s. 104 Rn. 201. Kapsamlı bilgi için bkz. aşa. IV, A, 5.

29 Gauch, 2011, Rn. 1331; Schwarze, s. 19; Arpac1, s. 148-149; MüKoBGB/Busche, BGB $\$ 642$ Rn.11; Eren, 2019, s. 1135; Vygen/ Joussen, s. 418 Rn. 1066; Kleine-Möller/ Merl/ Glöckner, $₫ 2$ Rn. 24; Öz, s. 114; Ünal, s. 446; Peters, s. 645; Erman, BGB $₫ 643$ Rn. 3; Staudinger, s. 115 Rn. 62; Palandt, $₫ 642$ Rn. 2; Kapellmann, s. 193; Aldemir Toprak, s. 238. Kapsamlı bilgi için bkz. aşa. IV, A, 2.

Bkz. VOB/B $\$ 4$ ve SIA-Norm 118 Art. 116. Dünnweber, Inge (1984) Vertrag zur Erstellung einer schlüsselfertigen Industrieanlage im internationalen Wirtschaftsverkehr, Berlin, Walter de Gruyter, s. 80; Gauch, 2011, Rn. 1331; Nicklisch, s. 534, 538; MüllerFoell, s. 88; Aldemir Toprak, s. 239-240. Kapsamlı bilgi için bkz. aşa. IV, A, 5.

31 Bkz. VOB/B § 5. Fuchs, s. 72-73, s. 220-221; Arpacı, s. 133. Kapsamlı bilgi için bkz. aşa. IV, A, 6.

32 Bkz. SIA-Norm 118 Art. 34. Peters, s. 644; Ünal, s. 446; Palandt, $₫ 642$ Rn. 4; Kapellmann, s. 193; Gauch, 2011, Rn. 1332-1333; MüKoBGB/Busche, BGB $₫ 631$ Rn. 108; Nicklisch, s. 533-534; Locher/ Locher, s. 105 Rn. 204. Kapsamlı bilgi için bkz. aşa. IV, A, 8. Endüstriyel tesislerde var olan iş birliği eylemlerinin türleri hakkında kapsamlı bilgi için bkz. Nicklisch, s. 534; Dünnweber, s. 80; Gauch, 2011, Rn. 1331; Aldemir Toprak, s. 238240.

Dünnweber, s. 74, 80; Nicklisch, s. 539; Gauch, 2011, Rn. 1331. Karş. Esser/ Weyers, s. 285; Aldemir Toprak, s. 240. Kapsamlı bilgi için bkz. aşa. IV, A, 7. Nicklisch, s. 534, 539; Arpacı, s. 154.

36 Gerekli izin ve onayların yüklenici tarafından alınabileceği görüşü bkz. Schwarze, s. 20. Yüklenicinin inşaat plânını hazırlayabileceği görüşü için bkz. Nicklisch, s. 539. 
bazı yasal düzenlemelere ${ }^{37}$ göre esas itibariyle, iş sahibi tarafından yerine getirilmesi gerekir. Ancak yüklenicinin de yerine getirmesi gereken bazı iş birliği eylemleri vardır. Bu eylemler esas itibariyle, iş sahibinin iş birliği eylemlerinin karşılığını oluşturur. Örneğin, iş sahibi tarafından hazırlanan belgelerin kontrolü ${ }^{38}$, var olan eksik ve ayıplar hakkında onu bilgilendirme ${ }^{39}$, verilen talimatların olumsuz sonuçları hakkında uyarma ${ }^{40}$ (TBK m. 476) bu şekildedir. Ayrıca, birlikte çalıştı̆̆ 1 yükleniciler ile koordineli hareket etme ${ }^{41}$, verilen talimatlara uyma ve iş sahibinin denetim hakkını kullanmasına müsaade etme yüklenici için bir iş birliği eylemidir ${ }^{42}$.

Belirtmek gerekir ki, bahsi geçen tüm iş birliği eylemlerinin, kimin tarafından yerine getirileceği kesin olarak belirlenmemektedir. Örneğin, İmar Kanunu, yapı kullanım izni alma görevini, iş sahibine yüklemektedir (İK m. 30). Yine Alman VOB/B'e göre, iş sahibi, yükleniciye inşa eserine ilişkin plânları temin etmelidir. Ancak izin ve onayların yüklenici tarafından alınacağının veya plânları onun hazırlayacağının kararlaştırılması mümkündür $(\mathrm{VOB} / \mathrm{B} \$ 3)$. Dolayısıyla, her bir inşaat sözleşmesinde, iş birliği eyleminin kim tarafından gerçekleştirileceği, sözleşme içeriğine bakılarak tespit edilir ${ }^{43}$.

\section{III. İŞ BİRLİĞİ EYLEMLERİNIN HUKUKÎ NİTELİĞi}

\section{A. KÜLFET GÖRÜŞÜ}

İş birliği eylemleri, Türk Borçlar Kanunu'nda düzenlenmemektedir. Bu sebeple, iş birliği eyleminin hukukî niteliği belirlenmelidir. Bu konuda,

37 İnşaat izinlerine ilişkin bkz. İK m. 22 ve 30. İnşaat plânlarının hazırlanması ve teslimi için bkz. BİGŞ m. 10; YİGŞ m. 13; VOB/B $₫$ 3; SIA-Norm 118 Art. 34. İnşaat arsasının hazırlanması ve teslimi için bkz. BİGŞ m. 30; YİGŞ m. 32 . Bkz. VOB/B \$ 3. Fuchs, s. 184; Schwarze, s. 29. Kapsamlı bilgi için bkz. aşa. IV, B, 2. Fuchs, s. 184. Kapsamlı bilgi için bkz. aşa. IV, B, 3. Bkz. VOB/B \$ 4. Schwarze, s. 32; Fuchs, s. 185. Kapsamlı bilgi için bkz. aşa. IV, B, 3. Bkz. BGH, Urteil vom 30.09.1969- VI ZR 254/67 (Braunschweig), NJW 1970, 38. Kapsaml bilgi için bkz. Schwarze, s. 45-46.

Kapsamlı bilgi için bkz. aşa. IV, B, 4 .

Gauch, 2011, Rn. 1334. 
doktrinde farklı görüşler ileri sürülmektedir. Ancak belirtmek gerekir ki, burada ifade edilen görüşlerin büyük bir kısmı, yalnız iş sahibinin iş birliği eylemlerini dikkate alarak belirleme yapmaktadır.

Doktrinde ileri sürülen görüşlerden ilki külfet görüşüdür ${ }^{44}$. Bu görüşe göre eserin imaline ilişkin iş birliği eylemleri, iş sahibi için bir külfet (obliegenheit) niteliğindedir. Ancak bu eylemlerin külfet olmayacağ kararlaştırılabilir. İsviçre Hukukundaki ağırlıklı görüşe göre de iş birliği eylemleri, külfet niteliğindedir ${ }^{45}$. Alman Hukukunda da iş birliği eylemlerinin külfet olduğu, ağırlıklı olarak kabul edilmektedir ${ }^{46}$. Öyle ki, Alman Medenî Kanunu'nun, iş sahibinin borçlarına kanunda yer verdiği ve iş birliği eylemlerini bu kapsamda düzenlemediği ileri sürülmektedir ${ }^{47}$.

Külfet görüşüne göre iş sahibi, eserin imali için gerekli olan külfeti yerine getirmez veya bunda gecikirse, alacaklı temerrüdü (TBK m. 106 vd.) söz konusu olur. Nitekim, BGB $\$ 642$ hükmü de iş sahibin iş birliği eylemlerini ihlâli için alacaklı temerrüdü hükümlerine atıf yapmaktadır. Yargıtay da vermiş olduğu bir kararında ${ }^{48}$, iş sahibinin iş birliği eylemlerine aykırı hareket etmesi nedeniyle, alacaklı temerrüdü hükümlerine (TBK m. 106 vd.) başvurmuştur.

44 Gauch, 2011, Rn. 1325, 1328; Fikentscher/ Heinemann, $₫ 84$ Rn. 1201, $\$ 45$ Rn. 489; Staudinger, s. 115 Rn. 62, s. 683 Rn. 17; Erman, BGB $₫ 642$ Rn. 4; Esser/ Weyers, s. 285; Palandt, $₫ 642$ Rn. 3; Ünal, s. 450; Larenz, 1987, s. 389; Peters, s. 643-644; Seçer, s. 488; Larenz, 1986, s. 370; Gauch, s. 23-24. Karş. MüKoBGB/Busche, $₫ 642$ Rn. 13-14; Eren, Fikret (2019) Borçlar Hukuku Genel Hükümler, 24. Bası, Ankara, Yetkin Yayınları, s. 1135; Vygen/ Joussen, s. 422 Rn. 1073. Ancak Gauch, Larenz, Satudinger ve Plandt'a göre aksi mümkündür. Bkz. Larenz, 1987, s. 389; Staudinger, s. 115 Rn. 62; Palandt, $₫ 642$ Rn. 3; Gauch, s. 24. Ayrıca bkz. aşa. III, C. Kural olarak külfet olduğu görüşü için bkz. Koller, Alfred (1998) Der Werkvertrag, Art. 363-366 OR Schweizerisches Zivilgesetzbuch, Das Obligationenrecht, Die einzelnen Vertragsverhältnisse, Bern, Verlag Stämpfli AG, Art. 366 Rn. 774; Koller, Art. 363 Rn. 293. Somut olayın şartlarında da bakılması gerektiği görüşü için bkz. Seçer, s. 488.

Açıklama için bkz. Schwarze, s. 92; Dünnweber, s. 81; Locher/ Locher, s. 60 Rn. 133.

Peters, s. 643.

Bkz. Yarg. 15. HD. T. 22.04.2008, E. 2007/ 3118 K. 2008/ 2682 (KBİBB, 818/m. 90, 355; 1086/m. 409/5) s.e.t. 10.03.2020. 


\section{B. YÜKÜMLÜLÜK GÖRÜŞÜ}

İş birliği eylemlerini, iş sahibi bakımından ele alan bir görüşe $e^{49}$ göre inşaat sözleşmelerinde söz konusu eylemler, külfet değil, yükümlülük teşkil eder. $\mathrm{Bu}$ görüşe göre iş sahibinin iş birliği eylemlerini, külfet olarak düzenleyen ve yalnız istisnaen sözleşmenin içeriği sebebiyle, yükümlülük olabileceğini ileri süren hâkim görüş, eserin inşasına ve ifa sürecine uymaz. Zira bu süreçte, kural olarak inşaat projesinin gerçekleştirilmesi son derece karmaşıktır. Bu karmaşıklık ise inşa eserinin meydana getirilmesi sürecinde, yüklenici ve iş sahibinin iş birliği yapmasını zorunlu kılar. Bu sebeple, inşaat sözleşmelerinde iş sahibinin gerçek iş birliği eylemleri, külfet değildir; aksine yükümlülük olarak değerlendirilmelidir ${ }^{50}$. Bu anlamda, inşaat sözleşmelerinde iş birliği eylemlerinin genel olarak yan edim yükümlülügü olduğu kabul edilmektedir $^{51}$. Alman Federal Mahkemesi vermiş olduğu bazı kararlarında ${ }^{52}$ iş birliği eylemlerini, yükümlülük olarak nitelendirmektedir.

İş birliği eylemlerinin yükümlülük olduğu kabul edilirse, söz konusu eylemin yerine getirilmemesi halinde borçlu temerrüdü (TBK m. 117 vd.) söz konusu olur. Diğer taraf, iş birliği eyleminin yerine getirilmesini talep edebilir; yerine getirilmediği takdirde ise ifa davası açabilir. Yine iş birliği eyleminin yerine getirilmemesi sebebiyle uğranılan zararın tazmini istenebilir.

\section{SOMUT OLAYIN ŞARTLARINA GÖRE BELİRLENMESİ GEREKTİĞİ GÖRÜŞÜ}

Doktrinde ileri sürülen diğer bir görüş, iş birliği eylemlerinin hukukî niteliğini, külfet veya yükümlülük olarak baştan belirlemek yerine, somut

49 Kapellmann, s. 193; Erman, BGB $₫ 643$ Rn. 2; Koller, Art. 366 Rn. 776; Spiess, s. 121.

50 Spiess, s. 121.

51 Spiess, s. 121; Larenz, 1987, s. 389; Arpacı, s. 184. İş birliği eylemlerinin yükümlülük olarak nitelendirilmesi halinde, yan yükümlülük (Nebenpflicht) olduğu görüşü için bkz. Koller, Art. 366 Rn. 776.

52 BGHZ 11, 80 f., NJW 1954, 229. Kararın değerlendirilmesi için bkz. Nicklisch, s. 535. Ayrıca bkz. BGH 13.07.2000, VII ZR 139/99, BauR 2000, 1762; ZfBR 2000, 548. Kararın değerlendirmesi için bkz. Fuchs, s. 14-16. Aynı yönde bkz. BGH, Urteil vom 21.10.1999VII ZR 185/98 (München), NJW 2000, 1336. 
olayın şartlarına bakılması gerektiğini ifade etmektedir ${ }^{53}$. Bu görüşe göre, inşaat sözleşmesi için ilgili iş birliği eyleminin önemi dikkate alınmalıdır. Zira her iş birliği eylemi, tarafların ortak çalışması için eşit derecede gerekli değildir $^{54}$. İş birliği eylemi, yerine getirilmediği takdirde, sözleşmenin amacı tehlikeye giriyor, özellikle bu amacın gerçekleşmesi kat'i bir şekilde engelleniyorsa, bir yükümlülük olarak değerlendirilmelidir ${ }^{55}$. Ayrıca bu belirlemede, dürüstlük kuralı da dikkate alınmalıdır ${ }^{56}$. İş sahibinin iş birliği yapmasında, yüklenicinin menfaati var ve bu olmaksızın, yüklenici kendi edimini yerine getirebilecek durumda değilse, eylemin bir yükümlülük olduğu kabul edilmelidir ${ }^{57}$.

\section{GÖRÜŞLERİN DEĞERLENDİRILLMESI VE GÖRÜŞÜMÜZ}

İş birliği eylemlerinin hukukî niteliğini, özellikle eser sözleşmesini dikkate alarak belirlemeye çalışan farklı görüşler bulunmaktadır. Bunlardan külfet görüşü, doktrinde ağırlıklı olarak kabul edilen görüştür. Ancak iş birliği eylemlerini, külfet olarak niteleyen bu görüş ${ }^{58}$, yukarıda da belirtilmiş olduğu üzere tarafların istisnaen aksini kararlaştırabileceklerini ileri sürmektedir. Bu sebeple, iş birliği eylemlerini külfet veya yükümlülük olarak nitelendiren iki görüşün, aslında birbirine yakınlaştığı ileri sürülmektedir ${ }^{59}$.

Alman Medenî Kanunu, eser sözleşmesine ilişkin düzenlemelerinde, iş sahibinin iş birliği eylemlerini, külfet olarak görmekte ve yerine getirmemesi halinde alacaklı temerrüdü hükümlerine atıf yapmaktadır (BGB $\$$ 642). Doktrinde ${ }^{60}$ bu durumun, özellikle tamir ve iyileştirme gibi zanaat işlerinde geçerli olduğu ifade edilmektedir. Zira burada dar bir yükümlülük kapsamı

\footnotetext{
3 Schwarze, s. 93; Nicklisch, s. 535; Seçer, s. 488. Ancak Seçer'e göre iş sahibinin iş birliğinde bulunma borcu, çoğu zaman külfet niteliğindedir. Bkz. Seçer, s. 488.

54 Schwarze, s. 93. 
vardır. Ayrıca edimlerin bir kere değiş tokuş yapıldığı ve iş sahibinin rolünün, eseri teslim almak ile sınırlı olduğu sözleşmeler de bu kapsamda tutulur. Zira bu sözleşmelerde, iş sahibinin iş birliği eylemleri, onları borç olarak nitelendirmeyi haklı gösterecek anlam ve yoğunluğa ulaşmaz. Aksine bilgi ve iş birliği gereksinimi, söz konusu eser sözleşmelerinde, her iki taraf içinde dardır. Öte yandan, malzeme, teknik ve zaman bakımından kapsamı dar olan basit yenileme veya genişletme gibi küçük inşaat işlerinde de sözleşmenin ifası süresince yüklenicinin menfaati, ücretini almaktan öteye gitmez. Bu sözleşmelerde, iş sahibinin iş birliği eylemleri özel bir anlama sahip değildir ${ }^{61}$. Doktrinde $^{62}$, BGB $₫ 642$ hükmünün, eser sözleşmesinde iş sahibinin iş birliği eylemlerini külfet olarak sınıflandırsa bile, özellikle değişen koşullar ve ihtiyaçlar göz önüne alındığında, sözleşmenin farklı bir yorumu için açık olduğu ifade edilmektedir. Ayrıca bu görüşe göre BGB $₫ 642$ hükmü ile iş birliği eylemlerinin, yerine getirilmemesi halinde, karşılık ödeme yükümlülüğü öngörülerek iş birliği eylemlerinin yalnız iş sahibinin menfaatine olmadığ açıkça ortaya koyulmaktadır. Zira yüklenicinin uygun bir bedel talep edebilmesi, iş sahibinin iş birliği eylemini yerine getirmesi için bir baskı aracıdır.

Her ne kadar hâkim görüş, iş birliği eylemlerini külfet olarak nitelendirmekteyse de doktrinde haklı olarak belirtildiği üzere bu hususun, tüm inşaat sözleşmeleri için doğrudan kabulü mümkün değildir. Zira taraflar, sözleşme özgürlüğü ilkesi (TBK m. 26) doğrultusunda, külfetlerin yükümlülük olacağını açıkça kararlaştırabilirler ${ }^{63}$. Taraflar, iş birliği eyleminin yükümlülük olduğunu, asıl veya ek sözleşme ile düzenleyebilirler. İnşaat hukuku uygulamalarında ise iş sahibinin, iş birliği eylemlerini yerine getirmekle yükümlü olduğu sözleşmede belirtilir ${ }^{64}$. Dolayısıyla, tarafların inşaatın kararlaştırıldığı şekilde imali için gerekli olan iş birliği eylemlerinin, kimin tarafından ne şekilde yerine getirileceğini veya yerine getirmemenin sonuçlarını belirleyip belirlemediklerine bakılmalıdır. Tarafların

\footnotetext{
61 Schwarze, s. 92.

63 Larenz, 1987, s. 389; Schwarze, s. 93; Gauch, s. 25; Nicklisch, s. 540. 
belirlemelerine göre söz konusu iş birliği eyleminin külfet veya yükümlülük olduğu sonucuna varılabilir. Tüm bu tespitler, sözleşmenin yorumu ile gerçekleştirilmektedir $^{65}$. Belirtmek gerekir ki, iş birliği eyleminin yükümlülük olduğu yönündeki önemli bir gösterge, onun sözleşmede yer almasıdır. Çünkü bu şekilde, her iki tarafın menfaati o eylemin ifasında birleşir. Bir iş birliği eylemi, sözleşmede ayrıntılı bir şekilde belirlenmiş veya belirlenebilir nitelikte ise borçlu temerrüdü hükümleri (TBK m. 117 vd.) uygulanır. Ancak iş sahibinin iş birliği yapma hususunda vermiş olduğu genel taahhütler, tek başına bir yükümlülük olarak nitelenemez ${ }^{66}$.

Taraflar iş birliği eylemini, sözleşme ile düzenlememiş olabilirler. Var olan düzenleme, hukukî niteliğin belirlenmesi için yetersiz de kalabilir. Tüm bu hallerde, söz konusu iş birliği eyleminin külfet olduğunu kabul etmek her zaman doğru olmaz. Zira özellikle iş sahibinin iş birliği eylemlerinin hukukî niteliğinin belirlenmesi, onun bu eylemi yerine getirmesinde, yüklenicinin menfaat sahibi olup olmadığı ile yakından ilgilidir ${ }^{67}$. Öyle ki, sözleşme dikkate alınarak her iki tarafın menfaatinin objektif analizinden, söz konusu iş birliği eyleminin yükümlülük olduğu sonucu çıkarılabilirr ${ }^{68}$. İnşaat sözleşmelerinin ise özel bir yapısı vardır. Bu sözleşmeler, esas itibariyle uzun meydana getirme süresine sahiptir. Ayrıca inşaat sözleşmelerinin bazıları, projenin büyüklüğüne ve içerdiği edimlerin kapsamına göre eser sözleşmesinin özelliklerinden bir hayli uzaklaşabilir. Bu durumun sonucu olarak her sözleşmede yüklenicinin bir inşa eserinin meydana getirilmesindeki tek menfaatinin ücret alacağ olduğu söylenemez. Aksine yüklenicinin eserin tamamlanmasına ilişkin korunmaya değer başka menfaatleri bulunabilir. Şöyle ki, yüklenicinin eserin meydana getirilmesiyle ilgili korunmaya layık görülen menfaati, öncelikle böyle bir yapının başarıyla inşası halinde, rekabet avantajı elde etmesine ilişkindir. Yüklenici, daha fazla büyük inşaat projesi almak için böyle eserlerin meydana getirilmesinde yetenekli olduğunu, eseri inşa ederek kantlamak ister. $\mathrm{Bu}$, teknik olarak yeni bir tesisin başarılı bir şekilde uygulandığını

\footnotetext{
65 Gauch, s. 25; Nicklisch, s. 540.

66 Seçer, s. 492.

67 Stassen/ Grams, s. 947.

68 Schwarze, s. 94.
} 
ispatlayabilen pilot projelerde özellikle önemlidir. Ayrıca kötü iktisadî koşullarda, bir yüklenicinin varlığı, bu tür büyük yapıların inşasına bağlı olabilir $^{69}$. Söz konusu durum, yüklenicinin yalnız ücret ile ilgilendiği saf eser sözleşmesinden farklıdır. Dolayısıyla, iş sahibinin ikili bir rolünün bulunduğu, yani hem tamamlanan eserin alacaklısı hem de yapım aşamasında, yüklenicinin iş birliği ortağ 1 olduğu söylenebilirr ${ }^{70}$. Gerçekten iş birliğinin yükümlülük olarak nitelendirilmesi, iş sahibinin söz konusu eyleminin sonuçlarından ve yüklenici için öneminden kaynaklanabilir. İş birliğinin yerine getirilmesi, yüklenicinin aslî ediminin ifasına imkân verebilir. Bu yerine getirme, sözleşme menfaatine veya amacına ulaşmak için karşı edimi aşan bir öneme sahip olabilir. Bu halde, iş birliği eyleminin, bir yükümlülük olduğu kabul edilmelidir ${ }^{71}$. Dolayısıyla, iş sahibinin, iş birliği eylemlerini, sözleşmenin amaç ve mantığını dikkate alarak genel yorum kurallarına göre nitelendirmek gerekir $^{72}$. Bu bakımdan, biz de somut olayın şartlarının değerlendirilmesi görüşüne katılarak eser sözleşmesi bakımından ağırlıkta olan külfet görüşünün, özellikle büyük yapıları konu alan inşaat sözleşmeleri için her zaman ve olayda geçerli olmayacağı kanaatindeyiz. Somut olayda, her bir sözleşmenin içeriği, inşaatın niteliği, tarafların iradesi ve söz konusu eylemin inşa eseri için arz ettiği önem, diğer tarafın menfaati olup olmadığı tespit edilerek sonuca varılmalıdır. Yüklenicinin iş birliği eylemleri bakımından ise yine öncelikle sözleşmede bu yönde bir hüküm olup olmadı̆̆ değerlendirilmelidir. Sözleşmede bir hüküm bulunmadığı durumlarda, iş sahibinin bu eylemin yerine getirilmesindeki menfaati ve bu eylem olmaksızın eserin sözleşmede kararlaştırıldığı şekilde inşa edilip edilmeyeceği değerlendirilmelidir. $\mathrm{Bu}$ değerlendirmeye göre yüklenicinin iş birliği eyleminin külfet veya yükümlülük olduğu sonucuna varılabilir.

69 Bu konuda kapsamlı bilgi için bkz. Dünnweber, s. 83; Nicklisch, s. 540; Schwarze, s. 94.

Dünnweber, s. 83; Nicklisch, s. 537.

Schwarze, s. 94.

72 Nicklisch, s. 540. Karş. MüKoBGB/Busche, BGB $₫ 642$ Rn. 22. Tarafların somut olaydaki hukukî menfaatleri dikkate alınarak bir belirleme yapılmalıdır. Bu görüş için bkz. MüllerFoell, s. $75 \mathrm{vd}$. 
Kanaatimizce bir iş birliği eyleminin, sözleşmenin içeriğine veya bahsi geçen kriterlere göre bir yükümlülük olduğu sonucuna varılsa dahi, bu eylemlerin kural olarak yan edim yükümlülüğü olduğu söylenmelidir. Zira eserin meydana getirilmesi aşamasında, iş birliği yükümlülükleri gerekli olsa da kural olarak bunlar, synallagma ilişkisinde yer almazlar. Dolayısıyla da söz konusu iş birliği yükümlülükleri, tarafların asli edimlerini oluşturmazlar ${ }^{73}$.

\section{TARAFLARIN İŞ BİRLİĞİ EYLEMLERINIIN TÜRLERİ}

\section{A. İŞ SAHİBİNIN İŞ BİRLİĞİ EYLEMLERİ}

\section{Genel Olarak}

İnşa eserinin sözleşmeye uygun olarak meydana getirilebilmesi için, iş sahibi tarafından yapılması gereken eylem ve işler, onun iş birliği faaliyetini ifade eder ${ }^{74}$. Kararlaştırılan ücretin ödenmesi ve tamamlanan eserin teslim alınması yükümlülükleri dışında iş sahibi, eserin meydana getirilmesi için kural olarak bir dizi iş birliği eyleminde bulunmalıdır ${ }^{75}$.

Eserin, sözleşmede öngörüldüğü şekilde inşası, genellikle iş sahibinin, iş birliği eylemlerini ifasına bağlıdır ${ }^{76}$. Çünkü iş birliği eylemleri, birçok eserin inşasında, genellikle tüm sözleşme sürecini kapsar şekilde, iş sahibinin katılımını gerektirir ${ }^{77}$. İnşaat sözleşmesinde de iş sahibinin iş birliği eylemleri, sözleşmenin yerine getirilmesi için esaslı bir öneme sahiptir. Öyle ki, inşaat arsasının ve plânların teslimi, gerekli onayların alınması ile yüklenici eseri meydana getirmeye başlayabilir ${ }^{78}$.

73 Peters, s. 643; Nicklisch, s. 541. Bir görüşe göre esasen, iş sahibinin asli yükümlülükleri, ücret ödemek ve tamamlanan eseri teslim almaktır. İstisnai olarak, iş birliği yükümlülükleri, sözleşme uyarınca, synallagmatik ilişkide asli yükümlülük olarak da nitelendirilebilir. Bu, yüklenicinin sözleşmenin ifasında, fazlaca menfaati olması durumunda, kabul edilir. Pilot inşaat projeleri, bu duruma örnek gösterilebilir. Bkz. Nicklisch, s. 541.

74 Ünal, s. 444.

Dünnweber, s. 80; Vasconcellos, s. 94; Nicklisch, s. 538, 539; Müller-Foell, s. 86-87;

Erman, BGB $₫ 642$ Rn. 1; Ünal, s. 445; Aldemir Toprak, s. 235.

76 Erman, BGB $₫ 643$ Rn. 1; Nicklisch, s. 533; Ünal, s. 445; Larenz, 1986, s. 370; Fuchs, s. 76. 
İş birliği eylemleri, her bir inşaat sözleşmesi bakımından farklılık arz eder. Ancak yine de bu eylemleri, doktrin, mahkeme kararları ve uygulama doğrultusunda genel olarak sıralamak mümkündür. İşs sahibinin sahip olduğu iş birliği eylemlerinin başlıcaları, inşaat arsasının hazırlanması ve teslimi, gerekli izin veya onayların sağlanması, plânların verilmesi ya da tedarik hatlarının inşasıdır. Ayrıca iş sahibi, çalıştırmakta olduğu farklı yükleniciler arasında koordinasyonu sağlamalı, yükümlülük listesini hazırlamalı ${ }^{79}$, nasıl bir eser istediğini tarif etmeli ${ }^{80}$, yüklenici ile müzakere halinde bulunmalıdır. Lakin, iş birliği eylemleri bunlarla sınırlı değildir. Doktrinde ${ }^{81}$ eserin imali için gerekli malzemenin sağlanmasının da iş sahibinin bir iş birliği eylemi olduğu ifade edilmektedir. Ancak özellikle meydana getirilmesi tam veya genel yükleniciye bırakılan inşaat sözleşmelerinde, bu edimin yüklenici tarafından gerçekleştirileceği kararlaştırılmaktadır. Yine eser teslim sözleşmesinde ve anahtar teslim inşaat sözleşmesinde (Schlüsselfertiger Vertrag) ${ }^{82}$ malzeme yüklenici tarafından sağlanmaktadır.

Doktrinde ${ }^{83}$ yüklenicinin personeli için kalacak yerin bulunmasının, iş sahibi için bir iş birliği eylemi olduğu kabul edilmektedir. Bu eylem özellikle yüklenicinin ülkesinin dışında imal edilen inşaat için önem arz etmektedir. Ayrıca, iş sahibi, inşaattan çıkan kazı malzemeleri ve yüklenicinin araç veya gereçleri için depo yeri de göstermelidir (BİGŞ m. 4; YİGŞ m. 6) ${ }^{84}$. Öte yandan, iş sahibi, ifa sürecinde gerekli olan ara kararları almalı ${ }^{85}$ ve yükleniciyi inşaatın meydana getirilmesine ilişkin hususlarda bilgilendirmelidir ${ }^{86}$. İş

\footnotetext{
79 Kapellmann, s. 193. Aynı yönde bkz. VOB/A § 9. Kapsamlı bilgi için bkz. Schwarze, s. 25.

Palandt, $₫ 642$ Rn. 2; Ünal, s. 445.

81 Esser/ Weyers, s. 285; Ünal, s. 446; Larenz, 1986, s. 370; Gauch, 2011, Rn. 1332-1333; MüKoBGB/Busche, BGB $₫ 631$ Rn. 108; Nicklisch, s. 533-534.

Martinek, Michael (1993) Moderne Vertragstypen Band III: Computerverträge, Kreditkartenvertäge sowie sonstige moderne Vertragstypen, München, Verlag C. H. Beck, s. 246; Aldemir Toprak, s. 132. FIDIC Gümüş Kitap’ta yer alan benzer düzenleme için bkz. FIDIC EPC, N. 7.1

Nicklisch, s. 534, 539; Arpacı, s. 154.

Karş. SIA-Norm 118 Art. 116. Ayrıca bkz. Arpacı, s. 154.

Esser/ Weyers, s. 285.

Palandt, $₫ 642$ Rn. 2; Esser/ Weyers, s. 285.
} 
sahibi, yükleniciye ait araç gerece ve onun çalışanlarına özen gösterilmelidir ${ }^{87}$. Yine inşaat dokümanlarının hazırlanması ${ }^{88}$ ve yükleniciye ait olmasına rağmen, iş sahibinde bulunan evrakların geri verilmesi ${ }^{89}$ de iş birliği eylemidir.

İş sahibi, iş birliği eylemlerini, kural olarak kendisi yerine getirmek zorunda değildir. Eylemin ifasını üçüncü kişilere bırakabilir. Ancak söz konusu eylemin gerçekleştirilmesinde, iş sahibinin kişiliği önemli ise eylemin yerine getirilmesinin üçüncü kişiye bırakılması mümkün değildir ${ }^{90}$. İş sahibi yerine getireceği iş birliği eylemleri için kural olarak ücret talep edemez. Zira yükleniciye ödeyeceği ücret belirlenirken, iş sahibinin bu edimleri dikkate alınacaktır $^{91}$. Ancak bu eylemler neticesinde, iş sahibine ücret ödeneceği veya en azından iş sahibinin yapmış olduğu masrafların tamamı ya da bir kısmının yüklenici tarafından karşılanacağı kararlaştırılabilir.

\section{2. İnşaat Arsasının Hazırlanması ve Teslimi}

İnşaat sözleşmelerinde, arsasının hazırlanması ve yükleniciye teslimi, bir iş birliği eylemi olarak değerlendirilmektedir ${ }^{92}$. İş sahibinin arsayı hazırlaması, Türk Borçlar Kanunu'nda düzenlenmemektedir. Ancak Bayındırlık İşleri Genel Şartnamesi ve Yapım İşleri Genel Şartnamesi, iş sahibi kamu tüzel kişisinin, arsanın yükleniciye, iki taraf arasında tutulacak bir tutanak ile teslimini düzenlemektedir (BİGŞ m. 4; YİGŞ m. 6). Şartnamelerin kapsamına girmeyen inşaat işleri için söz konusu iş birliği eyleminin, sözleşme ilişkisinin doğasından da ortaya çıktığı söylenebilir ${ }^{93}$. Örneğin arsa payı

87 Erman, BGB $₫ 643$ Rn. 3; Esser/ Weyers, s. 285.

88 Fikentscher/ Heinemann, $\$ 84$ Rn. 1201.

89

Esser/ Weyers, s. 285.

90 MüKoBGB/Busche, BGB $\$ 640$ Rn. 6 .

91 Nicklisch, s. 539. BİGŞ m. 4 ve YİGŞ m. 6 da iş sahibinin arsayı hazırlama ve teslim etme eylemini, bedelsiz yapacağını ifade etmektedir.

92 Gauch, 2011, Rn. 1331; Schwarze, s. 19; Arpac1, s. 148-149; MüKoBGB/Busche, BGB $₫ 642$ Rn.11; Eren, 2019, s. 1135; Vygen/ Joussen, s. 418 Rn. 1066; Kleine-Möller/ Merl/ Glöckner, $₫ 2$ Rn. 24; Öz, s. 114; Ünal, s. 446; Peters, s. 645; Erman, BGB $₫ 643$ Rn. 3; Staudinger, s. 115 Rn. 62; Palandt, $₫ 642$ Rn. 2; Kapellmann, s. 193; Aldemir Toprak, s. 238.

93 Schwarze, s. 19; Aldemir Toprak, s. 238. 
karşılığı inşaat sözleşmesinde de böylesi bir iş birliği eyleminin varlığından bahsedilmelidir. Zira arsa sahibi, arsayı, projenin koşullarına uygun bir şekilde teslim ettikten sonra yüklenici inşaata başlayabilir.

İş sahibi, ihale öncesinde özellikle, arsanın özelliklerinin, yürütülen işin gereklerine uygun olup olmadığını tespit etmeli (SIA-Norm 118 Art. 5) ve arsayı inşaat için hazırlamalıdır (SIA-Norm 118 Art. 116). Gerçekten de iş sahibinin arsayı hazırlama ve teslimi eyleminin kapsamına, arsanın, inşaat için uygun ve kusur bulunmayan bir şekilde teslim edilmesi girer ${ }^{94}$. Yargitay da vermiş olduğu kararlarında ${ }^{95}$, iş sahibinin arsayı eserin inşasına başlanabilmesi için öncelikle inşaata elverişli ve ayıpsız teslim etmesi gerektiğinden bahsetmektedir. İnşaat arsasının elverişliliğgi, hukukî ve fiilî olarak sağlanmalı, bu elverişlilik inşaat süresince de korunmalıdır ${ }^{96}$. Bu bağlamda, iş sahibi, arsayı inşaat projesinin özelliklerine uygun ve elverişli bir şekilde teslim emelidir. Arsa üzerinde bulunan eserin inşasına engel olan sınırlı aynî haklar sona erdirilmelidir. Örneğin, arsa üzerindeki gecekondu yıkılmalı veya elektrik, su abonelikleri iptal ettirilerek yıkıma hazır hale getirilmelidir ${ }^{97}$. Ancak Bayındırlık İşleri Genel Şartnamesi ve Yapım İşleri Genel Şartnamesi ise işin meydana getirileceği arsada bulunan mevcut yapıların yıkımının, yükleniciye bırakılabileceğini düzenlemektedir (BİGŞ m. 30; YİGŞ m. 32).

İş sahibinin iş birliği eyleminin kapsamına, yüklenicinin inşaat arsasına erişimini sağlamak da dâhildir ${ }^{98}$. Bayındırlık İşleri Genel Şartnamesi ve Yapım İşleri Genel Şartnamesi de iş sahibi kamu tüzel kişisinin, iş için gerekli olan saha ve hizmet yollarının geçeceği yerlerin yükleniciye ücretsiz olarak teslim edileceğini ifade etmektedir (BİGŞ m. 4; YİGŞ m. 6).

\footnotetext{
94 Schwarze, s. 19; Arpacı, s. 149.

Bkz. Yarg. 15. HD. T. 22.04.2008, E. 2007/3118 K. 2008/2682 (KBİBB, 818/m. 90, 355; 1086/m. 409/5); Yarg. 15. HD. T. 02.04.2007, E. 2007/3, K. 2007/2035 (KBİBB, 818/m. 355); Yarg. 15. HD. T. 07.06.2004, E. 2003/6162, K. 2004/3152 (KBİBB) s.e.t. 10.03.2020.

96 Arpacı, s. 149. Aynı yöndeki karar için bkz. Yarg. 15. HD. T. 18.04.2019, E. 2018/2944, K. 2019/1865 (KBİBB, 6098/m. 470) s.e.t. 11.03.2020. Yarg. 15. HD. T. 22.04.2008, E. 2007/3118 K. 2008/2682 (КBİBB, 818/m. 90, 355; 1086/m. 409/5) s.e.t. 10.03 .2020

Nicklisch, s. 539.
} 
Tarafların, iş sahibinin böylesi bir iş birliği eylemi bulunduğunu ve bunun yerine getirilme zamanını kararlaştırmalarına bir engel bulunmamaktadır. Aynı şekilde iş sahibinin, arsayı teslim şekli, inşaata uygun olması için yapması gereken işlerin sözleşmede yer alması, ileride ortaya çıkabilecek uyuşmazlıkları da en aza indirebilir.

Bazı durumlarda, arsa henüz iş sahibinin mülkiyetinde bulunmayabilir. $\mathrm{Bu}$ halde, iş sahibi arsanın mülkiyetini elde edip, onu inşaat için hazırlayarak teslim edebilir. Ancak yüklenicinin arsanın mülkiyetini temin etmesi de kararlaştırılabilir. Bu durumda, iş sahibinin iş birliği eylemi, yükleniciye arsayı onun adına alabilmesi için vekâlet vermektir. Aksi kararlaştırılmamışsa, arsanın bedeli, iş sahibi tarafından karşılanmalıdır. Yine arsasının temin edilebilmesi için ödenecek bedelin ve masrafların karşılanması, inşaat sözleşmesi bakımından bir iş birliği niteliğindedir.

İnşaat arsasının hazırlanması eyleminin gereği gibi yerine getirilmemesi halinde, doğacak sonuçlara iş sahibi katlanır. Örneğin, arsasının, inşaata uygun olmaması sonrasında ortaya çıkan ek ücret riskini, iş sahibi taşı1 ${ }^{99}$. Türk Borçlar Kanunu'nda iş sahibinin bu iş birliği eylemine aykırı davranması sonucu eserin yok olması düzenlenmiştir (TBK m. 483) ${ }^{100}$. Buna göre inşa eseri, iş sahibi tarafından gösterilen arsanın ayıbı sebebiyle yok olmuş ise iş sahibi, yükleniciye yapılan işin değerini ve bu kapsama girmeyen giderleri ödemelidir. Ancak bunun için yüklenici, arsanın ayıplı ve eserin gereği gibi meydana getirilmesine engel olduğunu iş sahibine bildirmelidir ${ }^{101}$. Sadece bu koşullarda, iş sahibinin kusuru da varsa, zararın giderilmesi de istenebilir. TBK m. 483 hükmünde, iş sahibinin yükleniciye gösterdiği arsadan bahsedilmektedir. Kanaatimizce bu hükmün kapsamına, iş sahibinin temin ettiği veya temin edilmesini istediği arsa da girmelidir.

99 Schwarze, s. 19. Ayrica bkz. Gauch, 2011, Rn. 1331; Aldemir Toprak, s. 238-239.

100 Ayrıca TBK m. 483'e göre iş sahibinin sağladığı malzeme veya verdiği talimat sebebiyle eser yok olmuşsa, yüklenici, doğabilecek olumsuz sonuçları iş sahibine zamanında bildirmiş olmak kaydıyla, yaptığı işin değerini ve bu değere girmeyen giderlerinin ödenmesini isteyebilir.

101 Yüklenicinin yapacağı bu bildirim aynı zamanda iş birliği eylemidir. Bkz. aşa. IV, B, 3. 
İş sahibi, inşaatın yapılacağı arsayı hazırladıktan sonra yükleniciye teslim etmelidir ${ }^{102}$. Teslim, arsa üzerindeki fiilî hâkimiyetin, onun işe başlamasına imkân tanıyacak şekilde bırakılmasıdır. İş sahibinin bu eylemini yerine getirmemesi halinde, yüklenicinin inşa eserini meydana getirmeye başlaması mümkün olmaz. Bu halde, yüklenicinin işe zamanında başlamadığı veya eseri kararlaştırılan zamanda bitiremediği gerekçesiyle temerrüde düştüğünden bahsedilemez. Aksine iş sahibi, alacaklı (TBK m. 106 vd.) veya borçlu (TBK m. 117 vd.) temerrüdüne düşürülebilir.

\section{Gerekli İzin ve Onayların Alınması}

İzin, bir şey yapmak için verilen veya alınan ruhsat, icazet olarak tanımlanabilir ${ }^{103}$. Onay ise uygun bulmayı ifade etmektedir ${ }^{104}$. İzin ve onay hukukumuzda, esas olarak ilgilinin başvurusu üzerine, idarenin tek taraflı irade beyanıyla yapmış olduğu işlemi ifade etmektedir. İnşaat hukuku alanında, gerek inşaata başlanabilmesi gerekse de tamamlanmasının ardından kullanılabilmesi için izin ve onaylara ihtiyaç duyulur. Örneğin, İmar Kanunu'na göre inşaat ruhsatı (İK m. 22) ve yapı kullanım izni (İK m. 30) alma görevi, sözleşmede aksi kararlaştırılmamışsa, arsa sahibine aittir. Büyük çaplı inşaatta ise söz konusu izin ve onayların kapsamı daha geniştir.

İş sahibinin, iş birliği eylemlerinin, en tipik örneklerinden biri, gerekli izin ve onayların alınmasıdır ${ }^{105}$. Nitekim VOB/B $₫ 4$, BİGŞ m. 6 ve YİGŞ m. 8'e göre de iş sahibi, eserin meydana getirilmesi için gerekli izin ve onayları almakla yükümlüdür. Ancak yüklenicinin, izin ve onayları temin edeceğini

102 Aynı yönde bkz. Yarg. 15. HD. T. 05.05.2004, E. 2003/5372, K. 2004/2508. (KBİBB, 818/m. $81,90,106,35)$ s.e.t.12.03.2020.

103 Tanım için bkz. <https://sozluk.gov.tr> s.e.t. 13.02.2020.

104 Tanım için bkz. <https://sozluk.gov.tr> s.e.t. 13.02.2020.

105 Gauch, 2011, Rn. 1331; Schwarze, s. 20; Vasconcellos, s. 94; MüKoBGB/Busche, BGB $\$$ 642 Rn. 11; Nicklisch, s. 534, 538; Vygen/ Joussen, s. 417 Rn. 1062; Kleine-Möller/ Merl/ Glöckner, $\$ 2$ Rn. 24; Müller-Foell, s. 88; Eren, 2019, s. 1135; Staudinger, s. 263-264 Rn. 34; Ünal, s. 445; Öz, s. 114; Peters, s. 645; Palandt, $\$ 642$ Rn. 2; Kapellmann, s. 193; Aldemir Toprak, s. 239. 
kararlaştırmak mümkündür ${ }^{106}$. Nitekim çoğu kez, bu izinleri alma yükümlülüğü, yükleniciye verilmektedir ${ }^{107}$. Kanaatimizce bu durumda iş sahibi, yüklenicinin gerekli izni alması için vekâlet vererek veya diğer gerekli işlemleri ${ }^{108}$ sağlayarak iş birliği eylemlerini yerine getirmelidir. Özellikle yüklenicinin, iş sahibinin ülkesinde yapacağı inşaatta, buranın yabancısı olduğu için hukuk düzenlemeleri hakkında bilgilendirilmelidir. Bilgi verme yükümlülügü, söz konusu ülkenin emredici, teknik ve inşaat düzenlemelerine ilişkindir. Yine vergi ve harçlar, iş sahibi tarafından ödenmeyecekse, yüklenici bu konuda bilgilendirilmelidir ${ }^{109}$.

$\mathrm{VOB} / \mathrm{B} \$ 4$ düzenlemesini ele alan bir görüşe $\mathrm{e}^{110}$ göre gerekli izinlerin temin edilmesi, gerçek bir yükümlülüktür. Zira inşaat izni ve somut olayda gerekli diğer izinlerin ibrazı olmadan inşaat başlatılamaz ${ }^{111}$. Bu sebeple, iş sahibi gerekli izin ve onayları almaz veya yüklenici tarafından alınabilmesi için gerekli vekâleti ya da gerekli diğer işlemleri yapmaktan kaçınırsa eylemin ifası talep edilebilir.

\section{4. İnşaat Plânının Hazırlanması}

Plânlama, inşaat sözleşmeleri için önemli bir yer tutar. Bu çerçevede, doğru bir plânlama ile inşaat sözleşmesindeki karmaşıklık azalır. Bunun sonucunda, süre veya maliyetten tasarruf edilir. Doktrinde ${ }^{112}$ böylesine önemli

106 Schwarze, s. 20.

107 Nicklisch, s. 539; Öz, s. 148; Aldemir Toprak, s. 239. Bkz. Yarg. 15. HD. T. 01.07.2019, E. 2018/3907, K. 2019/3063 (KBİBB) s.e.t. 11.03.2020.

108 Yargıtay incelemesine konu olmuş bir olayda, iş sahibi, harç ve masrafları ödeyerek gerekli belgeleri teslim etmediği için yüklenici, yapı kullanım iznini (iskan belgesini) alamamıştır. Bkz. Yarg. 15. HD. T. 11.02.2019, E. 2018/2784, K. 2019/532 (KBİBB, 6098/m. 470; 818/m. 355) s.e.t. 11.03.2020.

109 Nicklisch, s. 539.

110 Seçer, s. 496.

111 Schwarze, s. 102.

112 Bkz. Schwarze, s. 20; MüKoBGB/Busche, BGB $₫ 642$ Rn. 11, BGB $₫ 631$ Rn. 108; Gauch, 2011, Rn. 1332-1333; Nicklisch, s. 534, 538; Eren, 2019, s. 1135; Kleine-Möller/ Merl/ Glöckner, $₫ 2$ Rn. 24; Esser/ Weyers, s. 285; Ünal, s. 445; Spiess, s. 120; Peters, s. 645; 
bir yer tutan inşaat plânlarının hazırlanmasının, iş sahibinin bir iş birliği eylemi olduğu ifade edilmektedir. Buna karşılık, büyük inşaat sözleşmelerinde bu eylemin, yükleniciye ait olduğu kabul edilebilir ${ }^{113}$. Zira bu sözleşmelerin, birden fazla edimi uzmanlık gerektirecek şekilde içermesi ve yükümlenicinin, iş sahibine göre daha uzman konumda olması, bu sonucu doğurmaktadır. Ayrıca bazı durumlarda iş sahibi, inşa eserini meydana getirme görevini, tam yükleniciye bırakmaktadır. Bu halde de inşaat plânları yüklenici tarafından hazırlanmaktadır ${ }^{114}$. Bayındırlık İşleri Genel Şartnamesi ve Yapım İşleri Genel Şartnamesi de projelerin iş sahibi kamu tüzel kişisi tarafından hazırlanması ve sözleşmenin imzalanması sırasında, yükleniciye teslim edilmesini öngörmektedir (BİGŞ m. 9; YİGŞ m. 11,12). Ancak ilgili yasal düzenlemelerde bu durum, emredici olarak düzenlenmemiş ve projelerin yüklenici tarafından da hazırlanabileceği ifade edilmiştir (BİGŞ m. 10; YİGŞ m. 13). SIA-Norm 118 düzenlemelerinde de aksi kararlaştırılmamışsa, plânları iş sahibinin hazırlaması gerektiğine yer verilmektedir (SIA-Norm 118 Art. 34).

İş sahibi, inşaat plânının hazırlanmasına dair iş birliği eylemini yerine getirirken, meydana getirmek istediği eserin nitelik ve özelliklerini dikkate almalıdır. Ayrıca yapmış olduğu plânlama, eserin sözleşmede kararlaştırıldığı şekilde meydana getirilmesine hizmet etmelidir. Bu sebeple, inşa eseri, öncelikle doğru ve zamanında plânlanmalıdır ${ }^{115}$. İş sahibinin plânları vermekte gecikmesi sebebiyle, yüklenici işe zamanında başlayamaz veya devam edemezse, yüklenicinin temerrüde düştügünden bahsedilemez (TBK m. 117 vd.).

İnşaat plânlarının yükleniciye teslimi, iş sahibinin bir eylem gerçekleştirmesini zorunlu kılar. Bu sebeple, söz konusu iş birliği eylemi, asli yükümlülüklerin yanında bağımsız bir öneme sahiptir ${ }^{116}$. İnşa eserinin sözleşmede kararlaştırıldığı şekilde meydana getirilmesi için plânların

Staudinger, s. 115 Rn. 62. Ayrıca bkz. Vygen/ Joussen, s. 413 vd. Rn. 1047 vd.; MüllerFoell, s. 87; Palandt, $\$ 642$ Rn. 2; Kapellmann, s. 193.

113 Nicklisch, s. 539.

114 Gauch, 2011, Rn. 233; Aldemir Toprak, s. 62.

115 Kapellmann, s. 193.

116 Schwarze, s. 102. 
hazırlanması ve teslimi gerekir. Bu sebeple, inşaat plânının hazırlanması ve teslimi, kural olarak yan edim yükümlülüğü niteliğindedir.

\section{5. İnşaat Arsasının Ölçümlenmesi ve Tedarik Hatlarının İnşası}

Bir inşa eserinin yapımına başlamadan önce, iş sahibi nasıl bir eser istediğini, yükleniciye tarif etmelidir ${ }^{117}$. Ancak bu bilgilendirme sonrasında yüklenici, söz konusu eserin meydana getirilmesinin mümkün olup olmadığını ve maliyetini iş sahibine bildirebilir. Bu bağlamda, söz konusu eserin nitelikleri, imal amacı, taşınması istenen veya istenmeyen özellikler detaylıca yükleniciye aktarılmalıdır. Bu kapsamda, iş sahibi, inşaat arsasını ölçümlemeli ve eserin sınırlarını belirlemelidir ${ }^{118}$. Böylelikle, inşaatın tam olarak nereye yapılacağı ve kat yüksekliği, iş birliği eylemi kapsamında tespit edilir $^{119}$. Nitekim arsanın ölçümlenmesi, SIA-Norm'da da bir iş birliği eylemi olarak yer almaktadır (SIA-Norm 118 Art. 114, 115).

Yüklenicinin eserin imaline başlayabilmesi, arsanın hazırlanması ve tesliminin yanında, eseri meydana getirmeye hizmet edecek tedarik hatlarının inşa edilmesine de bağlıdır. Doktrinde ${ }^{120}$, tedarik hatlarının inşasının, iş sahibi için bir iş birliği eylemi olduğu düşünülmektedir. Nitekim VOB/B $\$ 4$ ve SIANorm 118 Art. 116 da tedarik hatlarının inşasını, iş sahibinin iş birliği eylemi olarak düzenlemektedir. Ancak kanaatimizce, tedarik hatlarının yüklenici tarafından inşa edileceğinin kararlaştırılması da mümkündür.

Tedarik hatlarının inşası kapsamında iş sahibi, yüklenicinin arsaya erişimi için bir yol ve mecra yapmalıdır ${ }^{121}$. Gerek inşaat alanı içerisindeki geçiş yolları gerekse de ana yol bağlantılarının sağlanmasının, iş sahibinin iş birliği eylemlerinin kapsamına girdiği söylenebilir. Yine inşaat çalışmaları için

117 Palandt, $\$ 642$ Rn. 2; Ünal, s. 445.

118 Aynı yönde bkz. VOB/B \$ 3. Kapsamlı bilgi için bkz. Schwarze, s. 21; Arpacı, s. 139; Fuchs, s. 1045; Locher/ Locher, s. 104 Rn. 201. Yan yükümlülük olduğu yönünde bkz. Schwarze, s. 102.

119 Arpaci, s. 139-140.

120 Dünnweber, s. 80; Gauch, 2011, Rn. 1331; Nicklisch, s. 534, 538; Müller-Foell, s. 88; Aldemir Toprak, s. 239-240.

121 Gauch, 2011, Rn. 1331. Ayrıca bkz. Schwarze, s. 23; Ünal, s. 446; Aldemir Toprak, s. 240. 
gerekli olan su, ısıtma, aydınlatma ve diğer enerji bağlantıları sağlanmalıdır ${ }^{122}$. Zira bu tedarik hatları olmaksızın, eserin yüklenici tarafından sözleşmede kararlaştırıldığı şekilde meydana getirilmesi mümkün değildir. Ancak söz konusu eylemler yerine getirildiği takdirde, arsanın gerçek anlamda inşaata hazırlandığı söylenebilir.

\section{Yüklenicinin İfaya Çağrılması}

Taraflar, yüklenicinin ifaya başlama zamanını, sözleşmede kararlaştırabilirler. Bu kararlaştırma, bir tarih olabileceği gibi, belirli olgulara da bağlanabilir. Örneğin, çalışmaların yapı ruhsatı aldıktan sonraki bir ay içinde başlayacağının kararlaştırılmasında bu durum söz konusudur. Ayrıca ifaya başlama zamanı, işin niteliğinden de anlaşılabilir. Örneğin, plânlar teslim edilmeden veya iş sahibi gerekli malzemeleri sağlamadan, yüklenicinin işe başlaması mümkün değildir. Yüklenicinin işe ne zaman başlayacağının, iş sahibince belirlenmesi de istenebilir. Bu halde iş sahibi, gerekli şartlar oluştuktan sonra, ifaya başlaması için yükleniciye bildirimde bulunmalıdır. İş sahibinin söz konusu bildirimi, iş birliği eylemi niteliğindedir ${ }^{123}$. Nitekim, $\mathrm{VOB} / \mathrm{B} \$ 5$, iş sahibinin yüklenicinin edimini talep etmesine ve onu ifaya çağırması gerektiğine yer vermektedir. İş sahibi, bu talep ile yüklenicinin edimini gerçekleştirmesine imkân tanır ${ }^{124}$.

Alman Federal Mahkemesi vermiş olduğu bir kararında ${ }^{125}$, yüklenicinin ifaya çağrılmasını, yan yükümlülük olarak nitelendirmektedir.

\section{7. İșlevsellik Testlerine Katılma ve Ham Madde ile Personeli Temin} Etme

Bazı büyük inşaat sözleşmelerinde, yüklenicinin yerine getirmiş olduğu edimlerin doğruluğu ve uygunluğu, teslim öncesinde yüklenici tarafindan yapılacak işlevsellik testleri ile kanıtlanmaktadır. Özellikle, bir tesisin inşasını

\footnotetext{
122 Nicklisch, s. 538; Müller-Foell, s. 88.

123 Fuchs, s. 72-73, s. 220-221; Arpac1, s. 133.

124 Schwarze, s. 21.

125 BGH, Urteil vom 30.09.1971- VII ZR 20/70 (Düsseldorf), NJW 1972, 99.
} 
amaçlayan anahtar teslim inşaat sözleşmelerinde, işlevsellik testleri, yüklenicinin yerine getirmiş olduğu edimlerin seviyesine göre gerçekleştirilmektedir. Böylece yüklenici, söz konusu edimleri, eksiksiz bir şekilde yerine getirdiğini testler aracılığıyla kanıtlamaktadır ${ }^{126}$. Anahtar teslim inşaat sözleşmesinde iş sahibi tesisi gözden geçirme külfetini bu testlere katılarak sağlamaktadır ${ }^{127}$.

İşlevsellik testlerinin başarısında, iş sahibinin iş birliği eylemlerinin önemi büyüktür. İş sahibi, iş birliği eylemini, gerekli personel ve ham maddeyi test için bulundurarak gerçekleştirir ${ }^{128}$. İşlevsellik testlerinin başarısı, bazı durumlarda iş sahibinin bu iş birliği eylemini başarılı bir şekilde yerine getirmesine bağlıdır. Kanaatimizce, iş birliği eylemi yerine getirilirken ham madde, sözleşmede kararlaştırılan nitelik ve miktarda temin edilmelidir. Personel ise testin amacına göre yeterli kalifiye ve sayıda olmalıdır. Örneğin, mekanik tamamlama testi gerçekleştirilirken, montajdan anlayan personel, tesisin kapasitesini dikkate alınarak yeterli sayıda belirlenmelidir. Tesisin deneme testinde veya kabul için yapılan performans testinde, iş sahibi, tesisi sonrasında işletecek personeli bulundurmalıdır ${ }^{129}$. Temini istenen personelin sayısı ve nitelikleri ile ham maddeye dair özellikler, sözleşmede açıkça kararlaştırılabilir. Bir belirleme olmaması durumunda, iş sahibi söz konusu özellik ve niteliklerin yüklenici tarafından belirlenmesini veya kendisine bilgi verilmesini isteyebilir. Zira yüklenici, eseri imal eden kişidir. Dolayısıyla, yüklenici iş sahibine göre uzman kişi konumundadır. Nitekim yüklenicinin, iş sahibini bu konuda bilgilendirmesi, aynı zamanda onun iş birliği eylemini oluşturmaktadır.

126 İşlevsellik testlerinin türleri hakkında kapsamlı bilgi için bkz. Dünnweber, s. 72; Aldemir Toprak, s. 150-153.

127 Aldemir Toprak, s. 177.

128 Bkz. Dünnweber, s. 74, 80; Nicklisch, s. 539; Gauch, 2011, Rn. 1331. Karş. Esser/ Weyers, s. 285; Aldemir Toprak, s. 240.

129 Nicklisch, s. 539. 


\section{Yükleniciler Arasında Koordinasyonun Sağlanması}

a. Genel Olarak

Bir eser imal etmek isteyen iş sahibi, eseri öncelikle kendisi meydana getirmek isteyebilir. Bu halde, inşa eserini meydana getirme görevini kapsam, kalite, süre ve maliyetleri dikkate alarak iş sahibinin kendisi gerçekleştirir. Arsayı, malî kaynakları, inşaat projesini, mühendisleri ve diğer tedarikçileri, iş sahibi temin eder. Öte yandan, eserin plânlanması ve yapımı aşamalarında, gerekli izinleri ve onayları zamanında alarak düzgün bir inşaat süreci için ihtiyaç duyulan prosedürleri yerine getirir ${ }^{130}$. İş sahibi, kendisinin yerine getiremediği münferit işler için ise bu alanda yetkin bir yüklenici ile sözleşme imzalar. Birden fazla konuda yardıma ihtiyaç duyulursa, mühendislik, inşaat veya mekanik hizmetleri gibi alanlarda uzmanlaşmış birçok yüklenici ile sözleşme yapılır ${ }^{131}$. Bu durumda sözleşmeler, iş sahibinin koordinasyonunda gerçekleşir. Her bir yüklenicinin görevini tamamlamasıyla, inşa eseri ortaya çıkar ${ }^{132}$. İş sahibi, yükleniciler arasındaki koordinasyondan ve yükümlülüklerin gereği gibi yerine getirilmemesinden sorumlu olur. Ayrıca bütün projenin başarı riski de iş sahibinin üzerindedir ${ }^{133}$. Örneğin eserin önceki yüklenicinin çalışması sebebiyle ayıplı ortaya çıkmışsa, sonraki yüklenicinin bu ayıptan sorumlu tutulmaması gerekir. Ancak sonraki yüklenicinin TBK m. 476’a göre sorumluluktan kurtulabilmesi için ayıbın varlığını iş sahibine bildirmesi gerekmektedir. Yüklenicinin bilmesinin mümkün olmadığı ayıpları ise iş sahibine bildirmesi beklenmemelidir ${ }^{134}$. İş

130 Bauer, s. 24-25. Aynı yönde bkz. Krumm, Hein (1987) Anlagenverträge im Osthandel: Probleme beim Abschluß von Anlagenvertägen mit Partnern aus den Staatshandelsländern des RGW, Abhandlungen zum Recht der Internationalen Wirtschaft, Band 5, Heidelberg, Verlag Recht und Wirschaft, s. 19; Aldemir Toprak, s. 31.

131 Martinek, s. 243; Dünnweber, s. 6; Bauer, s. 25; Krumm, s. 19-20; Hautkappe, Bernhard (1986) Unternehmereinsatzform im Industrieanlagenbau, Abhandlungen zum Recht der Internationalen Wirtschaft Band 1, Heidelberg, Verlag Recht und Wirtschaft, s. 26 vd.

132 Martinek, s. 243; Dünnweber, s. 6; Hautkappe, s. 26.

133 Martinek, s. 243; Bauer, s. 25; Dayınlarlı, s. 34; Hautkappe, s. 27; Krumm, s. 19-20, 23.

134 Seçer, Öz (2016) "İnşaat Sözleşmesinde Yüklenicinin Bildirim Borcu", Bahçeşehir Üniversitesi Hukuk Fakültesi Dergisi, Prof. Dr. Özer Seliçi'nin Anısına Armağan, C: 11, S: 145-146, s. 727-754, s. 750. 
sahibi, yerine getirmesi gereken koordinasyon görevini gerçekleştirmek istemezse, müşavir mühendis ile anlaşabilir. Müşavir mühendis, eserin meydana getirilmesi için gerekli olan plânlama, koordinasyon ve denetim işlerini yerine getirir ${ }^{135}$. Neticede iş sahibi, farklı yüklenicilerin, finansman kurumlarının, danışmanların katıldığı çok sayıda sözleşme ile istediği eseri meydana getirmiş olur.

İş sahibi, eserin inşası için birden çok yüklenici ile anlaştığı durumlarda, bu yükleniciler arasındaki koordinasyonu sağlamalıdır. İş sahibinin söz konusu koordinasyonu sağlaması, bir iş birliği eylemidir ${ }^{136}$. SIA-Norm $118^{\prime} \mathrm{e}$ göre de iş sahibi, inşaatta yer alan tüm yüklenicilerin çalışmalarını zamanında koordine eder (SIA-Norm 118 Art. 34). Bu koordinasyon, inşa eserinin meydana getirilmesinde büyük önem arz eder. Koordinasyonun sağlanmasında yaşanan bir gecikme veya aksama, birçok sorunu beraberinde getirebilir. Örneğin, eserin meydana getirilmesinde yer alan ön yüklenicinin gecikmesi, sonraki yükleniciyi de geciktirirse, iş sahibi alacaklı temerrüdüne (TBK m. 106 vd.) düşer ${ }^{137}$. Ayrıca bu koordinasyondaki her bir aksama süre ve maliyet bakımından olumsuz sonuçlara yol açar.

İş sahibinin koordinasyonunun kapsamına, yüklenicilerin çalışmalarının alan, zaman ve teknik yönden koordine edilmesi de girer. Yüklenicilerin ifalarının zaman yönünden koordinesi için çizelge oluşturulabilir. Bu şekilde, eserin gereği gibi inşası için edimler, önceliklerine göre sıralanır. Ancak bazı durumlarda, yüklenicilerin işin doğası gereği, aynı alanda hizmet vermesi gerekebilir. Bu halde, birlikte çalışma için gerekli ayarlamalar yapılmalıdır. Nitekim, VOB/B $₫$ 4'e göre de iş sahibi, genel düzenin korunması için birden fazla yüklenicinin şantiyede ortak çalışmasını

135 Martinek, s. 243; Dünnweber, s. 6; Krumm, s. 23; Dayınlarlı, Kemal (1998) İnşaat Sektöründe Müşavir Mühendislik Sözleşmesi, Ankara, Dayınlarlı Hukuk Yayınları Ltd. Şti., s. 136-138.

136 Peters, s. 644; Ünal, s. 446; Palandt, $\$ 642$ Rn. 4; Kapellmann, s. 193; Gauch, 2011, Rn. 1332-1333; MüKoBGB/Busche, BGB $₫ 631$ Rn. 108; Nicklisch, s. 533-534; Locher/ Locher, s. 105 Rn. 204.

137 Koller, Art. 366 Rn. 777; Seçer, s. 496; Öz, s. 43-44. 
düzenlemekle yükümlüdür. Teknik yönden koordinasyon ise tesisat, elektrik ve su ihtiyaçlarının temin edilmesi şeklinde anlaşılmalıdır ${ }^{138}$.

b. Denetleme ve Talimat Verme Hakkı

Koordinasyon hakkı, iş sahibine inşaat işlerinin sorunsuz işleyebilmesi için gerekli olan talimatları verme yetkisi tanır. Talimat verme ve denetleme hakkı, bir bütünlük içerisindedir. Bu bağlamda, koordinasyon eyleminin gerçekleştirilmesi için yardımcı araç olarak iş sahibi, gözlem yapma ve talimat verme hakkına sahiptir (VOB/B $₫ 4)^{139}$.

İş sahibinin denetim yapması, inşa eserinin karmaşıklı̆̆ı sebebiyle, sonradan tespiti mümkün olmayan ayıpların, erkenden belirlenmesine hizmet eder. Denetleme hakkının bir sonucu olarak iş sahibi, şantiyeye giriş hakkına sahiptir. İşs sahibi, sözleşmede yer alan edimin kısmen dahi ifa edildiği atölye, iş yeri ve depolara giriş yapabilir. Bu giriş hakkı, dürüstlük kuralları ile sınırlanır ${ }^{140}$. Diğer bir anlatımla, iş sahibi söz konusu yerlerdeki denetlemelerinde bu hakkını kötüye kullanmamalıdır (TMK m. 2). İş sahibi, inşaat için kullanılan teknik resimleri veya diğer ifa belgelerini, para karşılığı verilen iş belgeleri olmadığı sürece, yükleniciden talep edebilir. Bu belgeleri talep hakkı, denetleme hakkının amacıyla sınırlıdır ${ }^{141}$.

İş sahibi, koordinasyon kapsamında yüklenicilere talimat verebilir. Ancak sadece yüklenicinin edim yükümlülüklerine ilişkin olarak talimat verilmesi de mümkündür ${ }^{142}$. Örneğin, hafriyat işini yapacak olan yükleniciye, montaj ile ilgili talimat verilemez. İş sahibi, talimatını yükleniciye sözlü veya yazılı bir şekilde iletebilir. Önemle belirtilmelidir ki, talimatın yazılı olması ileride ortaya çıkabilecek ispat sorunlarını en aza indirebileceği için tercih edilmelidir. İş sahibinin talimatlarının kendisi veya temsilcisi tarafından iletilmesinde de bir sakınca bulunmamaktadır ${ }^{143}$. Bu anlamda, talimatları iş sahibinin yetkili yardımcıları veya müşavir mühendis verebilir. Ancak somut

Arpaci, s. 141.

139 Bkz. Locher/ Locher, s. 104 Rn. 203; Schwarze, s. 22. Karş. SIA-Norm 118 Art. 34.

140 Schwarze, s. 23-24.

141 Schwarze, s. 24.

142 Schwarze, s. 25.

143 Arpaci, s. 143. 
olayda, talimatın niteliğine göre alt yüklenici veya ifa yardımcısına değil, yüklenicinin bizzat kendisine yapılması gerekebilir.

\section{B. YÜKLENICINIIN İŞ BİRLİĞİ EYLEMLERİ}

\section{Genel Olarak}

İnşaat sözleşmelerinde esas itibariyle, iş sahibi, iş birliği eylemlerinde bulunmayı üstlenmektedir. Ancak yüklenicinin yerine getirmediği takdirde, eserin inşasının sözleşmede kararlaştırıldığı şekilde gerçekleşmeyeceği bazı eylemleri de mevcuttur. İnşaat sözleşmelerinde iş birliği de tek tarafın eylemlerine bağlı olmayıp iki tarafın birlikte çalışmasını ifade eder. Yüklenicinin iş birliği eylemleri, her ne kadar iş sahibininkiler kadar kapsamlı olmasa da kanaatimizce onunkilerle iç içe geçmiş vaziyettedir. Ayrıca her somut olayda, yüklenicinin sahip olduğu iş birliği eylemleri, farklılık arz edebilir.

Yüklenicinin iş birliği eylemleri, esas itibariyle iş sahibinin iş birliği eylemlerinin karşılığını oluşturur. Bu bağlamda, yüklenici, iş sahibinin denetleme yapmasına, müsamaha göstermelidir. Aynı şekilde, iş sahibinin talimatlarını gerçekleştirmek yüklenicinin bir iş birliği edimidir. Bazı durumlarda iş sahibi, malzeme, doküman, depo, cadde ve bağlantıları veya tedarik hatlarını yükleniciye temin eder $^{144}$. Bu durumda, yüklenicinin, iş sahibinin kendisine bıraktığı mallarını özenli bir şekilde kullanması ve onları koruması gerekir. Nitekim, bu iş birliği eylemi, VOB/B'de açıkça düzenlenmektedir $(\mathrm{VOB} / \mathrm{B} \$ 8)^{145}$. Bayındırlık İşleri Genel Şartnamesi ve Yapım İşleri Genel Şartnamesi ise yükleniciye iş sahibi tarafından kendisine bırakılan kazıkları koruma zorunluluğu getirmektedir (BİGŞ, m. 4; YİGŞ m. 6). BİGŞ m. 7 ve YİGŞ m. 9 düzenlemelerinde, malzeme, araç gereç, iş ve hizmet makineleri ile yapılan işin bütün kısımlarının yüklenici tarafından sigorta ettirilmesi gerekliliğine yer verilmiştir. Yüklenicinin sigortası, deprem, yangın veya hırsızlı gibi olayları içerebilir. Ancak esasen bu risklerin kapsamını işs sahibi belirlemektedir.

\footnotetext{
144 Kapsamlı bilgi için bkz. yuk. IV, A, 5.

145 Schwarze, s. 30, 43. Karş. SIA-Norm 118 Art. 103.
} 


\section{2. İş Sahibi Tarafından Hazırlanan Dokümanları İnceleme}

Yüklenici, iş birliği eylemleri kapsamında, ihale öncesinde iş sahibi tarafından hazırlanan yükümlülük listesini ve ihale dokümanlarını kontrol etmelidir $^{146}$. İş sahibinin hazırlamış olduğu yükümlülük listesinin, meydana getirmek istediği esere uygun olup olmadığını incelemeli, bir eksiklik veya hata tespit edilmişse bu husus bildirilmelidir. Zira inşa eserinin meydana getirilmesinde, yüklenici iş sahibine nazaran uzman kişi konumundadır. $\mathrm{VOB} / \mathrm{B} ₫ 3$ ile de yükleniciye, iş sahibi tarafından kendisine verilen belgeleri kontrol etme ve onu uyarma zorunluluğu getirilmektedir. $\mathrm{Bu}$ kontrol yükümlülüğü ile inşa eserinin iş sahibinin belgelerindeki uyuşmazlıklar sebebiyle ayıplı veya projenin uygulanamaz olmasının önüne geçmek amaçlanmaktadır. Ayrıca böylelikle, ortaya çıkabilecek ayıp ve bozukluklar, yapım öncesinde bilinebilir ve keza gecikmeler de engellenebilir. Yüklenici bu incelemesini, sözleşmeden veya bilinen teknoloji kurallarından sapmaları belirlemek için yapmalıdır. Söz konusu bu inceleme, dikkatli ve özenli bir muayene ile sınırlıdır. Belirtmek gerekir ki, yüklenicinin inceleme yükümlülügü, iş sahibinin hatalı belge sunması nedeniyle, öncelikli olarak sorumlu olduğu gerçeğini değiştirmez. Ayrıca yüklenicinin inceleme zorunluluğu, daha önce deneyimlemediği, yeni bir teknik sistemin inşasında daha sinırlıdır ${ }^{147}$.

\section{3. İş Sahibini Bilgilendirme}

İş sahibini bilgilendirmek, inşaat sözleşmesinin yükleniciye yüklediği iş birliği eylemlerinden biridir. Bilgi paylaşımı ile inşa eserinin sözleşmede kararlaştırıldığı şekilde meydana getirilmesi sağlanır. Bu eylemin, hangi kapsamda ve şekilde olacağı, somut olayın şartlarına göre belirlenmelidir. Ancak bu kapsam ve sınırı belirlerken dürüstlük kuralı (TMK m. 2) dikkate alınmalıdır ${ }^{148}$. İş sahibinin bildiğini düşündüğü ve bunda haklı olduğu durumlarda, yükleniciden iş sahibiyle bilgi paylaşması beklenmemelidir.

\footnotetext{
146 Fuchs, s. 184; Schwarze, s. 29. Aynı yönde bkz. VOB/B $\$ 3$.

147 Schwarze, s. 31- 32.

${ }^{148}$ Fuchs, s. 181-182
} 
Ayrıca iş sahibinin bilgilendirilmesi, eserin imali ile ilgili olmalı ve yüklenicinin uzmanlık alanında bulunmalıdır.

Yüklenici, iş sahibini teslim etmiş olduğu dokümanlardaki çelişkiler, beklediği veya tespit ettiği ayıplar konusunda bilgilendirmelidir. Bilgi verme gerekliliği, bir görüşe göre sözleşmeden doğmaktadır ${ }^{149}$. Ancak inşaat sözleşmesinde yüklenicinin genel bildirim yükümlülüğünün TBK m. 473’ten kaynakladığı da ifade edilmektedir. Buna göre söz konusu hüküm olmasaydı dahi dürüstlük kuralı gereğince yüklenici, iş sahibini bilgilendirmekle yükümlü olurdu ${ }^{150}$. Bilgi verme zorunluluğunun görüldügü alanlardan bir diğeri, ek iş yapılması durumudur. Öyle ki, iş sahibi kanuna ${ }^{151}$ veya sözleşmeye dayalı olarak tek taraflı irade beyanıyla, ek iş yapılması talimatını verebilir. Yüklenici ise yapmış olduğu ek iş karşılığında, ek ücret ödenmesini talep edebilir. İş sahibi, ek iş talebinde bulunduğu takdirde, yüklenici edimin ifasına başlamadan önce onu, ortaya çıkacak ek ücret konusunda bilgilendirmelidir ${ }^{152}$. Kanaatimizce aynı durum, iş değişiklikleri için de geçerli olmalı, yüklenici, iş sahibini iş değişikliği sonrası ortaya çıkan ek ücret konusunda bilgilendirmelidir ${ }^{153}$.

Yüklenici, iş sahibinin talimatlarına karşı endişe ve kaygılarını ifade etmelidir $^{154}$. Burada yükleniciden, iş sahibinin talimatını bilimsel olarak ispatlanmış gerekçelerle çürütmesi beklenemez. Kanaatimizce yüklenicinin, kendisinden beklenen uzmanlıkla ve iş sahibinin anlayacağ şsekilde, kaygı veya endişelerini gerekçeli olarak açıklanması yeterlidir. Yoksa kesin, ispatlanmış

149 Fuchs, s. 184.

150 Seçer (2016), s. 728-729.

151 Türk Borçlar Kanunu'nda iş sahibine, iş değişikliği yapma ve ek iş verme hakkı tanıyan bir hüküm bulunmamaktadır. Kamu İhale Sözleşmeleri Kanunu’nda, sözleşme bedelinin aşılmaması ve iş sahibi kamu tüzel kişileri ile yüklenicinin karşılıklı olarak anlaşması kaydıyla, sözleşme hükümlerinde değişiklik yapılabileceği düzenlenmektedir. Ancak değişiklik yapma hakkı, sınırsız değildir (KİSK m. 15). Yapım İşleri Genel Şartnamesi'nde iş sahibine tek taraflı değişiklik yapma hakkı tanınmaktadır (YİGŞ m. 13).

152 Fuchs, s. 188. Ayrica bkz. Gökyayla, Emre (2009) Eser Sözleşmesinde Ek İş ve İş Değişikliği, İstanbul, Vedat Kitapçılık, s. 166-167

153 Konu hakkında kapsamlı bilgi için bkz. Gökyayla, s. 166-167.

154 Schwarze, s. 32; Fuchs, s. 185. Aynı yönde bkz. VOB/B $₫ 4$. 
delillere ihtiyaç duyulmamalıdır. İş sahibinden beklenen ise bu kaygı üzerine talimatını gözden geçirmesidir. Yüklenici, iş sahibinin talimatını, yasal düzenlemelere karşı gelmediği sürece yerine getirmelidir. Ancak iş sahibinin talimatı ile edimin sözleşmeye göre ifası arasında, bağlantı bulunmazsa veya talimat, dürüstlük kuralına uygun değilse, yüklenici, söz konusu talimatı yerine getirmekten kaçınabilir. Örneğin, teknik kurallara aykırı bir talimat verilmişse, yüklenici, bunu yerine getirmek zorunda değildir ${ }^{155}$. Bu bağlamda, İmar Kanunu'na veya diğer emredici inşaat düzenlemelerine aykırı talimatları yerine getirmesi yükleniciden beklenemez.

Bazı durumlarda yüklenici, iş sahibinden kaynaklanan bir nedenden veya mücbir sebepten dolayı, eserin inşasını belirlenen zamanda bitiremeyecek olabilir ${ }^{156}$. Yüklenici, iş sahibini duruma ilişkin derhal bilgilendirmelidir $^{157}$. Ancak Bayındırlık İşleri Genel Şartnamesi ve Yapım İşleri Genel Şartnamesi, bu halde yükleniciden süre uzatmaya yol açan sebebin ortaya çıkmasından itibaren on gün içinde, olayın ayrıntılarını, sonuçlarını ve gerekli olan ek süre miktarını bildirmesini beklemektedir. Ancak iş sahibi kamu tüzel kişisinin iş birliği eylemlerine aykırı davranması sebebiyle ek süreye ihtiyaç duyulmuşsa, bildirimin on gün içinde yapılması aranmamaktadır (BİGŞ m. 27; YİGŞ m. 30). Yine eserin inşa edileceği arsada bulunan değerli eşya hakkında, iş sahibi derhal bilgilendirilmeli, yetkililer tarafından teslim alınıncaya kadar da bu eşya muhafaza edilmelidir (BİGŞ m. 31; YİGŞ m. 33).

\section{Diğer Yüklenicilerle İş Birliği Yapma}

Bir inşa eserinin meydana getirilmesinde, birden çok yüklenicinin görev aldığı durumlarda, her birinin gerçekleştireceği ortak çalışma ile inşa eseri ortaya çıkar. Bazen yükleniciler arasında joint venture veya konsorsiyum gibi bir hukukî ilişki bulunur. Bu gibi hallerde yükleniciler birlikte çalışmakla

\footnotetext{
155 Schwarze, s. 24-25.

156 İş sahibinden kaynaklanan nedenler için bkz. Kurt, Leyla Müjde (2011) "Eser Sözleşmelerinde Süre Uzatımı”, BATİDER 2011, C: XXVII, S: 1, s. 157-206, s. 167 vd.

${ }^{157}$ Kurt, s. 197.
} 
yükümlü olurlar. Ancak bazı hallerde yükleniciler bir eser meydana getirmeyi birlikte üstlenmemektedirler. Bu halde, yüklenicilerden her bir yüklenici ile iş sahibi arasında birbirinden bağımsız sözleşme ilişkisi bulunur. Dolayısıyla, yükleniciler arasında iş birliği yapmalarını gerektiren bir sözleşme ilişkisi bulunmamaktadır. Aralarında sözleşme ilişkisi bulunmayan yüklenicilerin ise iş birliği yapması oldukça zordur. Zira yüklenicileri buna zorlayacak bir düzenleme bulunmamaktadır ${ }^{158}$. Ancak böyle bir durumda dahi yükleniciler arasında ortak bir amaç vardır. $\mathrm{Bu}$ amaç, yalnız eserin inşa edilmesidir. $\mathrm{Bu}$ amaç birlikteliği, yüklenicileri karşlıklı talep ve iş birliği ile yükümlü kılar. OLG Braunschweig vermiş olduğu bir kararında ${ }^{159}$, bazı durumlarda yükleniciler arasında böyle bir amaç birlikteliğinin olduğunu, kabul etmektedir. Buna göre yüklenicilerin hiçbiri, eseri veya ayrılabilir kısmını tek başına inşa edebilecek durumda değilse, aralarında amaç birlikteliğinin varlığ 1 kabul edilir. Yine yüklenici, birlikte çalışması gerektiğini bilerek işi almışsa, aynı sonuca varılır. Gerçekten de birden fazla yüklenicinin, bir eserin inşası ile görevlendirildiği hallerde, hepsinin ortak amac1, inşa eserinin sözleşmede kararlaştırıldığı şekilde, zamanında ve ayıpsız bir şekilde imalidir. Ancak yüklenicilerin iş birliği yapmaktan veya iş sahibinin koordinasyon eylemlerinden kaçınmaları ya da buna aykırı davranmaları halinde, eserin sözleşmeye göre inşa edildiğinden bahsedilemez. Bu sebeple, birden fazla yüklenicinin inşa eserinin meydana getirilmesini üstlendiği inşaat projelerinde, yüklenicilerin birbirleriyle iş birliği yapması bir iş birliği eylemi olarak nitelendirilmelidir. Bu halde iş birliği eylemi, sözleşmede yer almasa dahi, taraflar arasındaki amaç birlikteliğinin doğasından ortaya çıkmaktadır.

\section{V. İŞ BİRLİĞİ EYLEMLERİNE AYKIRILIĞIN SONUÇLARI}

\section{A. GENEL OLARAK}

İnşaat sözleşmesinde, iş birliği eylemi hiç veya gereği gibi yerine getirilmediği takdirde, diğer tarafın haklarının neler olacağı sorusu ortaya

158 Schwarze, s. 44.

159 Bkz. BGH, Urteil vom 30.09.1969- VI ZR 254/67 (Braunschweig), NJW 1970, 38. Kapsamlı bilgi için bkz. Schwarze, s. 45-46. 
çıkar. Bu çerçevede, iş birliği eyleminin ifasının istenip istenemeyeceği veya bunun ekonomik etkileri belirlenmelidir.

Taraflar, iş birliği eylemlerinin ihlâli halinde nasıl bir yol izlenmesi gerektiğini belirlemiş olabilirler. Bu durumda, tarafların yapmış oldukları düzenlemeler uygulanır. Örneğin, birlikte çalışmayı sağlayan bu eylemlerin yerine getirilmesini temin etmek için sözleşmede ceza koşuşuna yer verebilirler ${ }^{160}$. Ayrıca söz konusu eylemlerin, masrafı iş birliği sahibine ait olmak üzere, diğer taraf veya üçüncü bir kişi tarafından yerine getirileceği de kararlaştırılmış olabilir.

Yüklenici iş sahibinin iş birliği eylemlerini gereği gibi yerine getirmemesi sebebiyle, eserin meydana getirilmesi edimini ifada gecikirse, makul bir süre uzatımı isteyebilir ${ }^{161}$. Örneğin, iş sahibi, arsayı zamanında ayıpsız ve inşaata elverişli bir şekilde teslim etmediği veya gerekli izin ya da onayları almadığı için yüklenici işe geç başlamak zorunda kalabilir. Bayındırlık İşleri Genel Şartnamesi ile Yapım İşleri Genel Şartnamesi'nde de arsanın tesliminde yaşanan gecikme sebebiyle yüklenicinin işi kararlaştırılan sürede bitiremeyeceğinin anlaşıldığı hallerde, süre verilmesi gerektiği düzenlenmiştir (BİGŞ m. 4; YİGŞ m.6) Ayrıca iş sahibinin işlevsellik testlerine hiç katılmaması veya ham madde ya da personel temin etmekten kaçınması sebebiyle eser teste alınmamış veyahut teslim edilmemiş olabilir. Tüm bu durumlarda yüklenici, sözleşmede kararlaştırılan zamanda eseri teslim edememiş olsa da borçlu temerrüdüne (TBK m. 117 vd.) düşmemektedir. Zira söz konusu gecikme kadar bir süre, yüklenicinin ifa süresine eklenmektedir. Öte yandan, iş sahibinin iş birliği eylemlerini ihlâli haline bağlı olarak eser ayıplı bir şekilde meydana getirilmişse, iş sahibi ayıba bağlı hakları (TBK m. 475) kullanamaz ${ }^{162}$.

İş birliği yapmakla görevli olan tarafın, bu eylemi hiç veya gereği gibi yerine getirmemesi sebebiyle diğer taraf, masraf yapmak zorunda kalabilir. Örneğin, iş sahibi, yüklenicinin personeli için kalacak yer ayarlaması

\footnotetext{
160 Nicklisch, s. 543.

161 Aynı yönde bkz. Koller, Art. 366 Rn. 765; Seçer, s. 498.

162 Nicklisch, s. 542.
} 
gerekirken bunu yapmamış olabilir. Ayrıca koordinasyon eksikliğinden dolayı, işine vaktinde başlayamayan yüklenicinin, daha fazla masraf yapması mümkündür. Söz konusu hallerin tamamında iş sahibi, yüklenicinin yapmış olduğu ek maliyetleri karşılamalıdır ${ }^{163}$. Ancak bu taleplerin hukukî niteliği, iş birliği eyleminin hukukî niteliğinin yükümlülük veya külfet olarak belirlenmesine bağlıdır ${ }^{164}$.

İş sahibi, iş birliği eylemlerini kesin bir dille yerine getirmek istemediğini ifade ederse, bu irade beyanı tazminat karşıllı̆ı fesih olarak değerlendirilebilir (TBK m. 484) ${ }^{165}$. Ancak bu halde somut olayın şartları incelenmelidir. İş sahibinin iş birliği eylemini yerine getirmeyerek sözleşmeyi tek taraflı irade beyanıyla haklı sebeple sona erdirmek istediği sonucuna ulaşılırsa, temerrüt hükümleri (TBK m. 106 vd., 117 vd.) uygulanmaz. Aksine, TBK m. 484 hükmü uygulama alanı bulur. Buna göre iş sahibi, yapılmış olan kısmın karşılığını vermeli ve yüklenicinin bütün zararını gidermelidir ${ }^{166}$. Örneğin, iş sahibinin yükleniciyi ifaya çağırmaması ve onun arsaya girmesini engellemesi bu şekildedir. Ayrıca yüklenicinin işe başlaması için gerekli izin ve onayı temin etmemesi, yüklenicinin alması için vekâletini vermekten kaçınması hükmün kapsamına girebilir. Ancak somut olayda iş sahibinin yerine getireceği iş birliği eylemi basit bir katkıdan ibaret olabilir. Bu katkı, bütün inşaat projesi ile kıyaslandığında, önemsiz olarak addolunabilir. $\mathrm{Bu}$ durumda, iş sahibinin iş birliği edimini yerine getirmemesini tazminat

163 Gauch, s. 24; Gauch, 2011, Rn. 1336; Nicklisch, s. 542; Seçer, s. 500; Ünal, s. 452; Koller, Art. 366 Rn. 766. Ayrıca bkz. MüKoBGB/Busche, BGB $₫ 642$ Rn. 16-17; Vygen/ Joussen, s. 992 Rn. 2716; Kleine-Möller/ Merl/ Glöckner, $₫ 11$ Rn. 19; Fuchs, s. 126; Müller-Foell, s. 130; Erman, BGB $\$ 643$ Rn. 5; Spiess, s. 120; Larenz, 1986, s. 370.

164 Bkz. yükümlülük olan iş birliği eylemleri için aşa. V, B ve külfet olan iş birliği eylemleri için aşa. V, C.

165 Nicklisch, s. 542; Ünal, s. 453; Öz, s. 114. Karş. Esser/ Weyers, s. 285. Eser sözleşmesi, iş sahibi tarafından örtülü irade beyanıyla sona erdirilebilir. Bkz. Seçer, Öz (2020) Eser Sözleşmesinin İş Sahibi Tarafından Tam Tazminatla Feshi, Güncellenmiş 2. Baskı, Ankara, Yetkin Yayınları, s. 104-105.

166 Bu durumda iş sahibinin ödeyeceği tazminatın hesaplanması için doktrin ve uygulamada iki yöntem bulunmaktadır. Bunlar toplama ve çıkarma (menfi) yöntemleridir. Bu yöntemler hakkında kapsamlı bilgi için bkz. Eren (2019), s. 698 vd.; Seçer (2020), s. 335 vd. 
karşıllığ1 fesih olarak yorumlamamak gerekir ${ }^{167}$. Örneğin, bütün iş birliği eylemlerini ve diğer borçlarını yerine getiren iş sahibinin, işlevsellik testleri için getirmesi gereken ham maddeleri temin etmemesi bu niteliktedir.

Alman Medenî Kanunu'nda, iş sahibinin iş birliği eylemlerini yerine getirmemesinin sonuçları, açık bir hükümle düzenleme altına alınmıştır. $\mathrm{Bu}$ çerçevede BGB $\$ 642$ hükmünde, gerekli iş birliği eylemleri yerine getirilmemişse, yüklenicinin uygun bir karşllık talep edebileceği düzenlenmiş ve alacaklı temerrüdü hükümlerine atıfta bulunulmuştur. BGB $\$ 643$ hükmünde ise yükleniciye sözleşmeyi sona erdirme hakkı verilmiştir. Ancak bunun için yüklenici, öncelikle iş sahibine iş birliği eylemini yerine getirmesi için uygun bir süre vermelidir. Süre sonunda, iş birliği eylemleri yerine getirilmediği takdirde, yüklenicinin sözleşmeyi feshedebileceği belirtilmektedir. Bu halde, sözleşme ileriye etkili (ex nunc) bir şekilde sona erer. İş sahibi, eserin tamamlanan kısmı için uygun bir ücret ödemekle yükümlüdür (BGB $\$ 643)^{168}$. Görüldüğ̈̈ üzere, yükleniciye iş sahibini ifaya zorlama hakkı verilmemiştir ${ }^{169}$. Hukukumuzda ise iş birliği eyleminin yükümlülük veya külfet olarak nitelendirilmesine bağlı olarak uygulanacak kurallar ve tarafların sahip olacağı haklar farklılık arz etmektedir.

\section{B. YÜKÜMLÜLÜK OLAN İŞ BİRLİĞİ EYLEMLERİNE AYKIRILIĞIN SONUÇLARI}

Somut olayın şartları değerlendirildiğinde, iş sahibinin iş birliği eyleminin yükümlülük olduğu sonucuna varılabilir. Özellikle, yüklenicinin, iş sahibinin iş birliği eylemi olmaksızın edimini ifa edemeyeceği ve eserin meydana getirilmesinde menfaatinin olduğu büyük inşaat sözleşmelerinde durum böyledir. Bu hallerde, iş sahibi iş birliği eylemine aykırı davranırsa, yüklenici, iş sahibini borçlu temerrüdüne düşürebilir ve kanunun kendisine verdiği hakları kullanabilir (TBK m. 125). Ancak bunun için TBK m. 117'de

167 Ünal, s. 453.

168 Kapsamlı bilgi için bkz. MüKoBGB/Busche, BGB $₫ 643$ Rn. 3; Erman, BGB $₫ 643$ Rn. 1 vd.

169 Böyle bir zorlamanın olmaması, doktrin tarafından iş birliği eylemlerinin külfet olarak yorumlanmasına yol açmaktadır. Bkz. Arpacı, s. 167. 
aranan şartların gerçekleşmiş olması gerekir ${ }^{170}$. Buna göre iş birliği eyleminin ifasının mümkün ve muaccel olması, ancak buna rağmen eylemin yerine getirilmemesi gerekir. $\mathrm{Bu}$ bağlamda, inşaatın meydana getirmeye yeni başlandığı durumlarda, iş sahibinin yapı kullanım izin belgesini (iskan belgesini) almadığından yola çıkarak temerrüt hükümlerinin uygulanması düşünülemez. Zira inşaat henüz tamamlanmamış gerekli şartlar oluşmamıştır. Öte yandan, yüklenici, iş sahibine iş birliği eylemini yerine getirmesi için ihtar yapmalıdır. İhtar yerine geçen (TBK m. 117/2) veya ihtara gerek olmayan bir durum söz konusuysa, ihtarın yapılmış olması aranmaz. İş sahibi veya yüklenici, eylemi kabule hazır olup bundan kaçınma hakkı bulunmadığı takdirde, borçlu temerrüdüne düştügünden bahsedilebilir. İş sahibi veya yüklenicinin, iş birliği eylemini yerine getirmede kusurlu olup olmadığı ise, onun bu yükümlülük bakımından temerrüde düşmüşs sayılmasında önem arz etmez.

Taraflardan birinin iş birliği eylemini yerine getirmeyerek borçlu temerrüdüne düşülmüş olması, diğerinin artık ifa talep edemeyeceği anlamına gelmez. İfası mümkün olduğu sürece, iş birliği eyleminin yerine getirilmesi talep edilebilir ${ }^{171}$. Tarafların iş birliği eylemini yerine getirmemede kusuru bulunmaktaysa, aynen ifanın yanında gecikme tazminatının ödenmesi talep edilebilir (TBK m. 125/1). Taraf, söz konusu talepler yerine uğramış olduğu zararın giderilmesini isteyebilir ve sözleşmeden dönebilir (TBK m. 125/2). Yine, sözleşmeden dönerek menfi zararın giderilmesi talep edilebilir (TBK m. 125/3). Ancak bu hakların kullanabilmesi, TBK m. 124'te yer alan hallerden birinin bulunmadığı hallerde iş birliği eyleminin ifası için süre verilmesine bağlıdır. Mehil ile birlikte söz konusu iş birliği eylemi yerine getirilmediği takdirde TBK m. 125'te yer alan haklardan hangisinin kullanılacağ 1 bildirilmelidir. Yükümlülük olan iş birliği eylemlerini, külfet olanlardan ayıran özelliklerden biri ise tazminat talep edilebilmesidir ${ }^{172}$.

${ }^{170}$ Kapsamlı bilgi için bkz. Eren, 2019, s. 1224 vd.; Seçer, s. 489 vd.; Aldemir Toprak, s. 161 vd.

171 Spiess, s. 121.

172 Larenz, 1987, s. 390; Kapellmann, s. 197. 


\section{KÜLFET OLAN İŞ BİRLIĞĠ EYLEMLERINNE AYKIRILIĞIN SONUÇLARI}

Somut olayın şartları incelendiğinde, iş birliği eyleminin külfet niteliğinde olduğu sonucuna varılıyorsa, alacaklı temerrüdü hükümleri (TBK m. 106 vd.) uygulanmalıdır. İş birliği eylemini yerine getirmeyen tarafın, alacaklı temerrüdüne düşürülebilmesi için edimin, gereği gibi önerilmiş; ancak haklı bir sebep olmaksızın kabulden kaçınılmış olunması gerekir ${ }^{173}$. Yerine getirilmeyen iş birliği eyleminin ifası talep edilemez ${ }^{174}$. İş birliği eyleminin ihmali yoluyla, inşa eserinin meydana getirilmesinin engellenmesi, aksi kararlaştırılmadığı sürece tazminat talep etme hakkı vermez. Bu hukukî durum, iş birliği eylemlerinin külfet olduğu tespitine uygundur ${ }^{175}$.

Alman Hukukunda da gerek VOB/B $\$ 6$ gerekse de BGB $\$ 642$ düzenlemesi, yüklenicinin tazminat talep edemeyeceğini düzenlemektedir. Nitekim doktrinde ${ }^{176}$ de külfete aykırılık halinde tazminat talep edilemeyeceği ifade edilmektedir. BGB $₫ 642$ düzenlemesine göre iş birliği eylemi yerine getirilmediği takdirde, yalnız uygun bir bedelin ödenmesi talep edilebilir ${ }^{177}$. Bu talep, iş sahibinin kusurundan bağımsızdır ${ }^{178}$. Belirtmek gerekir ki, fazla ücret talebi yüklenicinin olası tazminat talebinden farklıdır ${ }^{179}$. Türk ve İsviçre Hukukunda ise uygun bir bedel ödenmesini içeren açık bir düzenleme bulunmamaktadır. Doktrinde ileri sürülen bir görüşe ${ }^{180}$ göre kanunda bu

173 Kapsamlı bilgi için bkz. Eren, 2019, s. 1338 vd.; Ünal, s. 451; Seçer, s. 493 vd.

174 Kapellmann, s. 193; Spiess, s. 121; Seçer, s. 500; Peters, s. 643; Stassen/ Grams, s. 947; Locher/ Locher, s. 60 Rn. 133.

175 Gauch, s. 25; Kapellmann, s. 193; Seçer, s. 500; Eren, 2019, s. 1137; Fuchs, s. 92; Arpacı, s. 73; Erman, BGB $₫ 643$ Rn. 8; Larenz, 1986, s. 370; Larenz, 1987, s. 390; Staudinger, s. 115 Rn. 62; Peters, s. 643.

176 Arpacı, s. 73; Erman, BGB $₫ 643$ Rn. 8; Larenz, 1986, s. 370; Larenz, 1987, s. 390; Staudinger, s. 115 Rn. 62.

177 Kapsamlı bilgi için bkz. Kapellmann, s. 193. İşs sahibi, külfet olan iş birliği eylemlerini yerine getirmekten kesin bir şekilde kaçındığında, yüklenicinin hakları BGB $\$ 642,643$ ve 645 ile sinırlı değildir. Bkz. BGH, Urteil vom 16.05.1968- VII ZR 40/66 (Celle), NJW 1968, 1873.

178 BGH, Urteil vom 21.10.1999- VII ZR 185/98 (München), NJW 2000, 1336.

179 Gauch, s. 24

180 Gauch, s. 24. 
hususta bir boşluk bulunmaktadır. Bu boşluk ise TMK m.1 uyarınca, hâkimin hukuk yaratması suretiyle doldurulur. Buna göre, aksi kararlaştırılmamışsa, alacaklı temerrüdüne dayanan ek masrafların karşılanması istenebilir. Diğer bir görüş ${ }^{181}$ ise Alman Hukukundan esinlenen bu görüşün hukukumuza uygulanamayacağını ifade etmektedir. Bu görüşe göre külfet olan iş birliği eylemlerine aykırılık sebebiyle yapılan masraflar, ücret olarak talep edilebilir. Şöyle ki, yaklaşık bedelle kurulan sözleşmelerde, yapılan ek masraflar, ücretin içerisinde yer alır. Götürü bedelle kurulan sözleşmelerde ise yapılan masraflar, bedel ile talep edilemez. Buna karşılık, ek masrafların ödenmesi, vekâletsiz iş görme (TBK m. 526 vd.) hükümlerine dayanılarak istenebilir. Kanaatimizce külfet olan iş birliği eylemlerine aykırılık sebebiyle ortaya çıkan masrafların, ücret olarak talep edilebileceği görüşü, sadece iş sahibinin iş birliği eylemlerine aykırılık halinde uygulama bulabilir. Zira inşaat sözleşmelerinde yüklenici, iş sahibine ücret ödemekle yükümlü değildir. Bu bakımdan, iş birliği eylemlerine uyulmazsa, yüklenici yapmış olduğu masrafları, sözleşmede aksine bir düzenleme bulunmadığı takdirde yalnız vekâletsiz iş görme hükümleri (TBK m. 526 vd.) kapsamında talep edebilir.

Doktrinde ${ }^{182}$ hatalı iş birliği eylemi sonucunda diğer tarafın hukukî varlığının zarar gördüğü durumlar farklı değerlendirilmektedir. Böylesi bir zarar için tazminat talebinde bulunulabilir. Çünkü iş birliği eylemlerine ilişkin bir yükümlülüğün olmaması, öngörülen iş birliği eylemi yoluyla, diğer tarafa zarar verme hakkı tanımaz. Aksine, işin yürütülmesi sırasında, karşı tarafı zararlardan korumak için makul ve mümkün olan her şeyi yapmak yan yükümlülük olarak kabul edilir.

İş birliği eylemlerinin yerine getirilmemesi sebebiyle, sözleşmeden dönülebilir (TBK m. 110). Bu durumda, alacaklı temerrüdü şartları gerçekleştiği takdirde, borçlu temerrüdünün şartlarına göre sözleşmeden dönülebilirr ${ }^{183}$.

181 Seçer, s. 502.

182 Gauch, s. 25.

183 İnşaat sözleşmesinin hangi hallerde geçmişe (ex tunc) veya ileriye (ex nunc) sona ereceği yönündeki değerlendirme için bkz. Aldemir Toprak, s. 296 vd. 


\section{SONUÇ}

İş birliği terimi, eserin türüne, özelliğine ve sözleşmenin içeriğine göre kararlaştırıldığı şekilde imali için gerekli olan eylemleri ifade eder. Tarafların iş birliği, inşa eserinin imali öncesinden, teslime kadar uzanan tüm süreci kapsar. İnşaat projelerinin giderek daha karmaşık bir hal alması ve proje başarısının her zaman risk altında olması, iş birliği eylemlerine verilen önem ile duyulan gereksinimi de arttırmaktadır.

Tarafların iş birliği eylemlerinin hukukî niteliği belirlenirken, eylemin sözleşmede açıkça kararlaştırılıp kararlaştırılmadığına bakılmalıdır. Zira taraflar sözleşme özgürlüğü (TBK m. 26) kapsamında iş birliği eylemi külfet veya yükümlülük olarak düzenleyebilirler. Sözleşmede bir hüküm bulunmadığı takdirde, hâkim görüş iş birliği eylemlerini, külfet olarak nitelendirilmektedir. Ancak bu görüş, bütün inşaat sözleşmelerinin özellikleriyle uyuşmamaktadır. $\mathrm{Bu}$ bağlamda, küçük inşaat işlerinde sözleşmenin ifası süresince yüklenicinin menfaati ücret almaktır. Bu tür sözleşmelerde, iş sahibinin iş birliği eylemlerinin özel bir anlamı yoktur. Ancak özellikle büyük çaplı inşaat projelerinde, yüklenicinin tek menfaati ücreti elde etmek değildir. Bu bakımdan, söz konusu sözleşmelerde iş birliği eylemlerinin külfet olduğu sonucuna doğrudan varılamaz. Ayrıca iş birliği olmaksızın eserin imalinin mümkün olup olmadığı da eylemin hukukî niteliğinin belirlenmesinde önemli bir kriterdir. Tüm bu değerlendirmelerden sonradır ki ancak iş birliği eyleminin yükümlülük veya külfet olduğu sonucuna varilabilir.

İnşaat sözleşmelerinin her biri, meydana getirilmesi taahhüt edilen eserin niteliğine göre farklılık arz etmektedir. Bu sebeple, kesin bir iş birliği eylemi listesi oluşturmak mümkün değildir. Ancak bu iş birliği eylemlerinin tipik örneklerini sıralamak mümkündür. Bu bağlamda, iş sahibi inşaat için arsayı hazırlamalı ve teslim etmeli, meydana getirmesi için gerekli izin ve onayları almalıdır. Yine eserin plânları hazırlanmalı, arsa ölçümlenmeli ve tedarik hatları inşa edilmelidir. Endüstriyel tesislerin meydana getirilmesini konu alan sözleşmelerde, işlevsellik testlerine katılma, ham madde veya personel temin etme, iş birliği eylemi olarak görülmektedir. Birden fazla yüklenicinin eserin meydana getirilmesi için iş görme edimini iş sahibine 
sunduğu durumlarda, onların zaman ve fonksiyonel olarak koordine edilmesi de iş sahibinin bir iş birliği eylemidir. Yüklenicinin yerine getirmesi gereken iş birliği eylemleri ise esas itibariyle, iş sahibinin iş birliği eylemlerinin karşılığını oluşturur. Bunlar, iş sahibi tarafından hazırlanan belgelerin kontrolü, var olan eksik ve ayıplar hakkında onu bilgilendirme, verilen talimatların olumsuz sonuçları hakkında uyarmadır. Ayrıca, birlikte çalıştığı yükleniciler ile koordineli hareket etme, verilen talimatlara uyma ve iş sahibinin denetim hakkını kullanmasına müsaade etme, yüklenici için bir iş birliği eylemidir. Tarafların söz konusu iş birliği eylemlerine aykırı davranmaları halinde uygulanacak hükümler ve diğer tarafın sahip olacağı haklar, eylemin hukukî niteliğine göre belirlenmelidir. Öyle ki, eylemin bir yükümlülük olduğu sonucuna ulaşılırsa borçlu temerrüdü (TBK m. 117 vd.) hükümleri uygulanır. Aksi halde, yani eylemin külfet olduğu sonucu ortaya çıkarsa, alacaklı temerrüdü hükümleri (TBK m. 106 vd.) uygulama bulur. 


\section{KAYNAKÇA}

Aldemir Toprak, İpek Betül (2020) Anahtar Teslim İnşaat Sözleşmesi, Seçkin Yayıncilik.

Arpacı, Özge (2019) Eser Sözleşmesinde İş Sahibinin Edimin İfasına Katılımı, Ankara, Yetkin Yayınları.

Aydemir, Efrail (2016) Eser Sözleşmesi ve İnşaat Hukuku, Güncellenmiş 3. Baskı, Seçkin Yayıncılık, Ankara, Haziran.

Bauer, Hermann (2007) Baubetrieb, 3. Aufl., Berlin Heidelberg, Springer Verlag.

Dayınlarlı, Kemal (1998) İnşaat Sektöründe Müşavir Mühendislik Sözleşmesi, Ankara, Dayınlarlı Hukuk Yayınları Ltd. Şti.

Dünnweber, Inge (1984) Vertrag zur Erstellung einer schlüsselfertigen Industrieanlage im internationalen Wirtschaftsverkehr, Berlin, Walter de Gruyter.

Eren, Fikret (1996) I. Borçlar Kanunu Açısından İnşaat Sözleşmeleri; II İnşaat Sözleşmelerinde Müteahhidin Borçları ve Bu Borçların Yerine Getirilmemesinin Sonuçları; III. İnşaat Sözleşmesinin Sona Ermesi, Yönetici-İsletmeci-Mühendis ve Hukukçular İçin Ortak Seminer, Banka ve Ticaret Hukuku Araştırma Enstitüsü Yayınları, 3. Tıpkı Basım, s. 47-103, Ankara.

Eren, Fikret (2019) Borçlar Hukuku Genel Hükümler, 24. Bası, Ankara, Yetkin Yayınları.

Erman, Walter Alexander (2011) Bürgerliches Gesetzbuch, (Hrsg. Harm Peter Westermann/ Barbara Grunewald/ Georg Maier-Reimer), 13., neu bearbeitete Aufl., Köln, Verlag Dr. Otto Schmidt.

Esser, Josef/ Weyers, Hans-Leo (1991) Schuldrecht: Ein Lehrbuch: Band II: Besonderer Teil, 7., völlig neuebearbeitete Auflage, Heidelberg, C. F. Müller Juristischer Verlag. 
Fikentscher, Wolfgang/ Heinemann, Andreas (2017) Schuldrecht Allgemeiner und Besonderer Teil, 11., völlig neu bearbeitete Aufl., Berlin/ Boston, Walter de Gruyter GmbH.

Fuchs, Heiko (2003) Kooperationspflichten der Bauvertragspartein, Baurechtliche Schriften Band 58, (Hrsg. Koorbion, H./ Locher, H.), München, Werner Verlag.

Gauch, Peter (1995) "Fristen und Termine - Die Bauzeit im Werkvertrag", Seminar für Schweizerisches Baurecht, Baurechtstagung 1995 / Tagungsunterlage 1, Freibrug.

Gauch, Peter (2011) Der Werkvertrag, 5. überarbeitete und erweiterte Aufl., Zürich, Schulthess Juristische Medien AG.

Gökyayla, Emre (2009) Eser Sözleşmesinde Ek İş ve İş Değişikliği, İstanbul, Vedat Kitapçılık.

Hautkappe, Bernhard (1986) Unternehmereinsatzform im Industrieanlagenbau, Abhandlungen zum Recht der Internationalen Wirtschaft Band 1, Heidelberg, Verlag Recht und Wirtschaft.

Kapellmann, Klaus Dieter (2011) "Die erforderliche Mitwirkung nach $₫ 642$ BGB, $\$ 6$ VI VOB/B - Vertragspflichten und keine Obliegenheiten", NZBau 2011, Heft 4, s. 193-197.

Kleine-Möller, Nils/ Merl, Heinrich/ Glöckner, Jochen (2014) Handbuch des privaten Baurechts, 5., neu bearbeitete und erweiterte Aufl., München, C.H. Beck Verlag.

Koller, Alfred (1998) Der Werkvertrag, Art. 363-366 OR Schweizerisches Zivilgesetzbuch, Das Obligationenrecht, Die einzelnen Vertragsverhältnisse, Bern, Verlag Stämpfli AG.

Krumm, Hein (1987) Anlagenverträge im Osthandel: Probleme beim Abschluß von Anlagenvertägen mit Partnern aus den Staatshandelsländern des RGW, Abhandlungen zum Recht der Internationalen Wirtschaft, Band 5, Heidelberg, Verlag Recht und Wirschaft.

Kurşat, Zekeriya (2017) İnşaat Sözleşmesi, Filiz Kitabevi. 
Kurt, Leyla Müjde (2011) "Eser Sözleşmelerinde Süre Uzatımı”, BATİDER 2011, C: XXVII, S: 1, s. 157-206.

Larenz, Karl (1986) Lehrbuch des Schuldrechts Band II: Besonderer Teil, 1. Halbband, 13. Aufl., München, C.H. Beck'sche Verlagsbuchhandlung.

Larenz, Karl (1987) Lehrbuch des Schuldrechts Band I: Allgemeiner Teil, 14. Aufl., München, C.H. Beck'sche Verlagsbuchhandlung.

Locher, Horst/ Locher, Ulrich (2005) Das private Baurecht, Lehrbuch für Studium und Praxis, 7. Neubearbeitete Aufl., München, Verlag C.H. Beck.

Martinek, Michael (1993) Moderne Vertragstypen Band III: Computerverträge, Kreditkartenvertäge sowie sonstige moderne Vertragstypen, München, Verlag C. H. Beck.

Müller-Foell, Christoph (1982) Die Mitwirkung des Bestellers beim Werkvertrag, Schriften zum Bürgerlichen Recht, Band 69, Berlin, Duncker \& Humblot.

Nicklisch, Fritz (1979) "Mitwirkungspflichten des Bestellers beim Werkvertrag, insbesondere beim Bau- und Industrieanlagenvertrag", BB 1979, Heft 11, s. 533-544.

Öz, M. Turgut (2016) İnşaat Sözleşmesi ve İlgili Mevzuat, İstanbul, Vedat Kitapçılık.

Palandt, Otto (2018) Bürgerliches Gesetzbuch mit Nebengesetzen, (bearbeitet von Brudermüller, Ellenberger, Götz, Grüneberg, Herrler, Sprau, Thorn, Weidenkaff, Weidlich, Wicke), 77. Neubearbeitete Aufl., München, Verlag C.H. Beck.

Peters, Frank (2011) "Die Mitwirkung des Bestellers bei der Durchführung eines Bauvertrags" NZBau 2011, Heft 11, s. 641-645.

Säcker, Franz Jürgen/ Rixecker, Roland/ Oetker, Hartmut/ Limperg, Bettina (Hrsg.) (2018) Münchener Kommentar zum Bürgerlichen Gesetzbuch, Band 5/1, Schuldrecht-Besonderer Teil III/1, 7. Aufl., München, C.H. Beck. (Kısaca: MüKoBGB/ Bölüm Yazarının Adı) 
Schwarze, Torsten (2003) Das Kooperationsprinzip des Bauvertragsrecht, Berlin, TENEA Verlag Für Medien.

Seçer, Öz (2016) “İnşaat Sözleşmesinde Yüklenicinin Bildirim Borcu”, Bahçeşehir Üniversitesi Hukuk Fakültesi Dergisi, Prof. Dr. Özer Seliçi'nin Anısına Armağan, C: 11, S: 145-146, s. 727-754.

Seçer, Öz (2017) "İş Sahibinin Teslim Borcundaki Gecikmeden Dolayı Sorumluluğu": Baysal, Başak/ İnal, Emrehan, İnşaat Hukuku ve Uygulaması, 1. Baskı, İstanbul, On İki Levha Yayıncılık.

Seçer, Öz (2020) Eser Sözleşmesinin İş Sahibi Tarafından Tam Tazminatla Feshi, Güncellenmiş 2. Baskı, Ankara, Yetkin Yayınları.

Spiess, Hans Rudolf (2012) "Bauablaufstörungen im schweizerischen Werkvertragsrecht”, recht 2012, Heft 4, s. 116-123.

Stassen, Dieter/ Grams, Hartmut (2003) "Zur Kooperationspflicht des Auftragnehmers gemäß $\$ 2$ Nr.5 VOB/B 2002 bei Mehrkosten”, baurecht 2003, Heft 7, s. 943-952.

Staudinger, Julius (2008) Kommentar zum Bürgerlichen Gesetzbuch: Staudinger BGB - Buch 2: Recht der Schuldverhältnisse: $\$ \$$ 631-651 (Werkvertragsrecht), Neubearbeitung, Berlin, Sellier- de Gruyter.

Ünal, Akın (2019) "Eser Sözleşmesinde İş Sahibinin İşbirliği Yapma Ödevi”, ERÜHFD, C: XIV, S: 2, s. 441-456.

Vasconcellos, Harald Michaelis (1988) Garantieklauseln und Risikoverteilung im internationalen Anlagenvertrag, Heidelberg, Verlag Recht und Wirtschaft GmbH.

Vygen, Klaus/ Joussen, Edgar (2008) Bauvertragsrecht nach VOB und BGB, Handbuch des privaten Baurechts, 4. Neu bearbeitete und erweiterte Aufl., Köln, Werner Verlag. 